Review

\title{
Cultivation and Biorefinery of Microalgae (Chlorella sp.) for Producing Biofuels and Other Byproducts: A Review
}

\author{
Chiu-Mei Kuo ${ }^{1,+}$, Yu-Ling Sun ${ }^{2,+}$, Cheng-Han Lin ${ }^{3}$, Chao-Hsu Lin ${ }^{3,4} \oplus$, Hsi-Tien Wu ${ }^{5}$ and Chih-Sheng Lin ${ }^{3,6,7, *}$ \\ 1 Bioresource Collection and Research Center, Food Industry Research and Development Institute, \\ Hsinchu 30068, Taiwan; cmk@firdi.org.tw \\ 2 Aquatic Technology Laboratories, Agricultural Technology Research Institute, Hsinchu 30068, Taiwan; \\ sylvia@mail.atri.org.tw \\ 3 Department of Biological Science and Technology, National Yang Ming Chiao Tung University, \\ Hsinchu 30068, Taiwan; a0975273923@gmail.com (C.-H.L.); 3099@mmh.org.tw (C.-H.L.) \\ 4 Department of Pediatrics, Hsinchu Mackay Memorial Hospital, Hsinchu 30071, Taiwan \\ 5 Department of BioAgricultural Sciences, College of Agriculture, National Chiayi University, \\ Chiayi 60004, Taiwan; htwu@mail.ncyu.edu.tw \\ 6 Department of Biological Science and Technology, National Chiao Tung University, Hsinchu 30068, Taiwan \\ 7 Center for Intelligent Drug Systems and Smart Bio-devices (IDS2B), National Yang Ming Chiao Tung \\ University, Hsinchu 30068, Taiwan \\ * Correspondence: lincs@mail.nctu.edu.tw; Tel.: +886-3-513-1338 \\ + These authors contributed equally to the manuscript.
}

\section{check for} updates

Citation: Kuo, C.-M.; Sun, Y.-L.; Lin, C.-H.; Lin, C.-H.; Wu, H.-T.; Lin, C.-S. Cultivation and Biorefinery of Microalgae (Chlorella sp.) for Producing Biofuels and Other Byproducts: A Review. Sustainability 2021, 13, 13480. https://doi.org/ $10.3390 /$ su132313480

Academic Editors: Praveen Ramasamy, Søren Laurentius Nielsen and MubarakAli Davoodbasha

Received: 6 November 2021

Accepted: 3 December 2021

Published: 6 December 2021

Publisher's Note: MDPI stays neutral with regard to jurisdictional claims in published maps and institutional affiliations.

Copyright: (c) 2021 by the authors. Licensee MDPI, Basel, Switzerland. This article is an open access article distributed under the terms and conditions of the Creative Commons Attribution (CC BY) license (https:/ / creativecommons.org/licenses/by/ $4.0 /)$.

\begin{abstract}
Microalgae-based carbon dioxide $\left(\mathrm{CO}_{2}\right)$ biofixation and biorefinery are the most efficient methods of biological $\mathrm{CO}_{2}$ reduction and reutilization. The diversification and high-value byproducts of microalgal biomass, known as microalgae-based biorefinery, are considered the most promising platforms for the sustainable development of energy and the environment, in addition to the improvement and integration of microalgal cultivation, scale-up, harvest, and extraction technologies. In this review, the factors influencing $\mathrm{CO}_{2}$ biofixation by microalgae, including microalgal strains, flue gas, wastewater, light, $\mathrm{pH}$, temperature, and microalgae cultivation systems are summarized. Moreover, the biorefinery of Chlorella biomass for producing biofuels and its byproducts, such as fine chemicals, feed additives, and high-value products, are also discussed. The technical and economic assessments (TEAs) and life cycle assessments (LCAs) are introduced to evaluate the sustainability of microalgae $\mathrm{CO}_{2}$ fixation technology. This review provides detailed insights on the adjusted factors of microalgal cultivation to establish sustainable biological $\mathrm{CO}_{2}$ fixation technology, and the diversified applications of microalgal biomass in biorefinery. The economic and environmental sustainability, and the limitations and needs of microalgal $\mathrm{CO}_{2}$ fixation, are discussed. Finally, future research directions are provided for $\mathrm{CO}_{2}$ reduction by microalgae.
\end{abstract}

Keywords: $\mathrm{CO}_{2}$ biofixation; biorefinery; biofuel; Chlorella; cultivation; microalgae

\section{Introduction}

Global population growth is increasing the demand for food, fiber, forage, and renewable biomass resources for energy, biofuels, and chemical products [1,2]. Policies must promote the long-term use of biomass and mitigation of climate change. Environmental pollution leads to global warming, i.e., via the emission of greenhouse gases (GHGs), which consist of approximately $72 \%$ carbon dioxide $\left(\mathrm{CO}_{2}\right), 19 \%$ methane $\left(\mathrm{CH}_{4}\right), 6 \%$ nitrous oxide and $3 \%$ fluorinated gases. $\mathrm{CO}_{2}$ is the principal GHG, and the emission of $\mathrm{CO}_{2}$ primarily results from the combustion of fossil fuels [3,4]. In 2015, the Paris Agreement claimed "net zero emissions of carbon" as a long-term global goal between 2050 and 2100. The United States (U.S.) National Oceanic and Atmospheric Administration (NOAA) reported that global average $\mathrm{CO}_{2}$ concentrations increased to approximately 417 ppm in 2020 and that the global $\mathrm{CO}_{2}$ rate is increasing annually. Rising GHG concentrations lead to global 
warming and climate change, which are believed to aggravate regional and global water scarcity [5,6]. Advanced strategies of $\mathrm{CO}_{2}$ mitigation have received increasing attention in the last decade [7-9], and many countries are actively immersed in processing/developing technologies to reduce GHGs [10,11].

Common carbon fixation or sequestration techniques include multidisciplinary physical [12,13], chemical [14], and biological [15,16] approaches. The biological approach of carbon fixation, i.e., $\mathrm{CO}_{2}$ biofixation, involves absorbing and utilizing $\mathrm{CO}_{2}$ by photosynthesis in autotrophic organisms or plants. Because solar energy is the main source required for $\mathrm{CO}_{2}$ biofixation, the operating costs are lower than those of chemical and physical methods. Additionally, fixed carbon can be converted into biomass for further applications, i.e., biomass can be recycled. Therefore, photosynthetic $\mathrm{CO}_{2}$ biofixation is a promising technology for carbon fixation [17,18]. As shown in Figure 1, microalgae are some of the most efficient photosynthetic organisms for $\mathrm{CO}_{2}$ biofixation as microalgae cultures have higher growth rates, higher conversion yields, lower demands for water, and smaller requirements for land area than terrestrial plants $[16,19,20]$. The factors of $\mathrm{CO}_{2}$ biofixation influence microalgal strains, $\mathrm{CO}_{2}$ from flue gas, nutrients from wastewater, light, $\mathrm{pH}$, temperature, and cultivation system [7,9,15-17]. Microalgal biomass is generally composed of approximately $50 \%$ carbon by dry microalgal cells because of the estimated $\mathrm{CO}_{0.48} \mathrm{H}_{1.83} \mathrm{~N}_{0.11} \mathrm{P}_{0.01}$ of the approximate molecular formula of microalgal biomass [21,22]. When microalgal biomass carbon is produced from $\mathrm{CO}_{2}$, approximately $1.83 \mathrm{~g} \mathrm{CO}_{2}$ is consumed to produce $1 \mathrm{~g}$ microalgal biomass $[23,24]$. The produced microalgal biomass can be utilized to produce lipids (oil) and carbohydrates as a source of chemical precursors and biofuels [25-28]. Palm oil mill effluent (POME) in microalgal cultivation is utilization to not only obtain the wastewater treatment by chemical oxygen demand (COD) reduction, but also the resulting microalgal biomass, to be a good feedstock as biofuels, such as biodiesel and bioethanol [1]. The maximum biomass production and lipid yield of Chlorella sp. in POME as medium was obtained in the optimal condition of $10.9 \% \mathrm{CO}_{2}$ and 9963.8 lux of light intensity through central composite designs [3]. The microalgal growth and lipid production were enhanced by the addition of phytohormone indole-3-butyric acid (IBA) [2], ferroferric oxide $\left(\mathrm{Fe}_{3} \mathrm{O}_{4}\right)$ nanoparticles [29], sodium nitrate $\left(\mathrm{NaNO}_{3}\right)$ [30], glycerol [31], etc. Additionally, the producing biomass microalgal $\mathrm{CO}_{2}$ fixation can be used to produce specific components that can be refined as high-value byproducts to realize the economic sustainability [32]. Based on the premise of complying with biosafety, the specific components of microalgae, such as lutein, $\beta$-carotene, zeaxanthin, fucoxanthin, and proteins can be further applied in food, animal feed, cosmetics, nutrient supplements, and pharmaceutical products [33-36]. Microalgae biological carbon fixation technology is beneficial at reducing carbon emissions, but how to achieve economic and environmental sustainability - at the same time-is a considerable challenge.

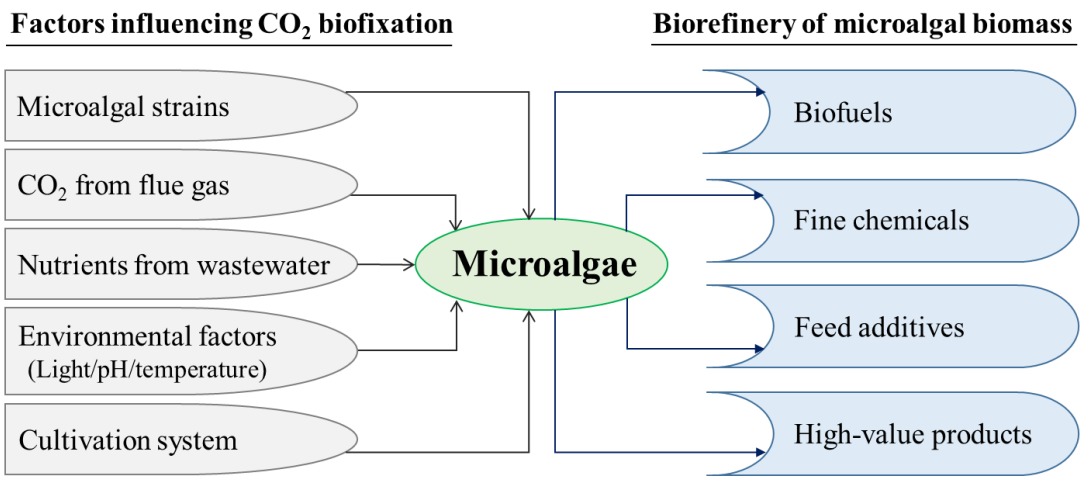

Figure 1. Microalgae-based carbon dioxide biofixation and biorefinery.

\section{Factors Influencing $\mathrm{CO}_{2}$ Biofixation by Microalgae}

The production of microalgal biomass is highly influenced by the suitability of microalgae strains, $\mathrm{CO}_{2}$, light, $\mathrm{pH}$, culture system, temperature, and nutrients [37-39]. The 
sources of $\mathrm{CO}_{2}$ and nutrients for microalgal cultivation can be flue gas and wastewater, respectively. Therefore, many studies have investigated whether flue gas and wastewater can be integrated with microalgal cultivations, to achieve not only $\mathrm{CO}_{2}$ reduction, but also $\mathrm{CO}_{2}$ reuse for microalgal biomass conversion to produce biofuels. Flue gas and wastewater can also be treated by microalgal cultivations to obtain environmentally friendly and health-friendly effects [25,40-43]. In the process of microalgae cultivation, one single factor does not affect the growth of microalgae; it is often the interaction of multiple factors [44]. Therefore, keeping the performance of long-term and stable microalgal cultivation will determine the microalgal growth, especially outdoor cultivation.

\subsection{Microalgal Strains}

Many studies have indicated highly efficient ways to obtain $\mathrm{CO}_{2}$-tolerant, alkali-tolerant, and/or thermotolerant microalgae with high $\mathrm{CO}_{2}$ fixation efficiency. Microalgal strains could be obtained by screening the environment, by random mutagenesis or by genetic modification (Table 1). Improving the capacity of $\mathrm{CO}_{2}$-tolerant microalgae was good for application in flue gas containing high concentrations of $\mathrm{CO}_{2}$ to reduce the $\mathrm{CO}_{2}$ poisoning effect and increase $\mathrm{CO}_{2}$ fixation productivity [45]. The level of $\mathrm{CO}_{2}$-tolerant microalgae is usually referred to as high, very high, and extremely high, according to ranges of $2-5,5-20$, and $20-100 \% \mathrm{CO}_{2}-$ tolerant concentrations [46]. As shown in Table 1, these strains not only have the ability to withstand very high $\mathrm{CO}_{2}$ concentrations, but also have better growth performances, to obtain higher $\mathrm{CO}_{2}$ fixation efficiency. Flue gas from steel plants containing approximately $25 \% \mathrm{CO}_{2}$, 70-80 ppm nitrogen oxides $\left(\mathrm{NO}_{\mathrm{x}}\right)$ and 80-90 ppm sulfur dioxide $\left(\mathrm{SO}_{2}\right)$ resulted in up to $90 \% \mathrm{NO}_{\mathrm{x}}$ and $\mathrm{SO}_{2}$, along with $50 \% \mathrm{CO}_{2}$ removal efficiency by the cultivation of Chlorella sp. MTF-15 [47,48]. Because $\mathrm{CO}_{2}$ is the main component in boiler flue gas with trace amounts of sulfur oxides $\left(\mathrm{SO}_{\mathrm{x}}\right)$, the resulting biomass after $\mathrm{CO}_{2}$ fixation may be used as an animal additive or feed without the concern of posing biosafety risks [49]. To improve the $\mathrm{CO}_{2}$ fixation efficiency, the screening of alkali-tolerant microalgae has been investigated [50-52]. It is known that when the $\mathrm{pH}$ of water is above 6.3 , dissolved $\mathrm{CO}_{2}$, bicarbonate $\left(\mathrm{HCO}_{3}{ }^{-}\right)$, and carbonate $\left(\mathrm{CO}_{3}{ }^{2-}\right)$ are the dominant species [53]. Therefore, elevated $\mathrm{CO}_{2}$ dissolution can be utilized in microalgae growth by increasing the $\mathrm{pH}$ of the culture medium. An alkali-tolerant Chlorella sp. AT1 was isolated and cultured in alkaline medium $(\mathrm{pH}=11)$ with $10 \% \mathrm{CO}_{2}$ aeration [50]. Chlorella sorokiniana SLA-04, which was isolated from alkaline Soap Lake, could adapt to growth in extremely high-pH media $(\mathrm{pH}>10)$ [51,52]. The high biomass productivities of Chlorella sorokiniana SLA-04 were obtained by scavenging $\mathrm{CO}_{2}$ from only the atmosphere at high rates in $\mathrm{pH}>10$ medium during phototrophic cultivation. Excessive light intensity will cause the internal temperature of the cultivation system to rise, causing the growth of microalgae to be inhibited. Two effective thermotolerant mutants, M18, and M24 of Chlorella pyrenoidosa obtained by mutagen treatment, were capable of surviving at temperatures up to $47^{\circ} \mathrm{C}$, and showed optimal growth at $37^{\circ} \mathrm{C}$ [54]. The research on screening specific algae strains in Table 1 is mainly in Taiwan, including the characteristics of $\mathrm{CO}_{2}$, alkali, and thermotolerance. However, in subtropical zones, the temperature of microalgal culture broth in PBRs can go up to about $40{ }^{\circ} \mathrm{C}$ by irradiation of sunlight [47], showing that the screening of thermotolerant strains is very important. The thermotolerance of Chlorella sp. M4, which was obtained by mutagenesis treatment from Chlorella sp. GD, was capable of overcoming high-temperature inhibition during outdoor culture due to high photosynthetic efficiency and biomass productivity at $40{ }^{\circ} \mathrm{C}$ with high-concentration $\mathrm{CO}_{2}$ aeration [55]. Thermotolerant microalgal strains can also be screened from high-temperature zones, such as the effluent of steel-making, power generation plants, and hot springs [56]. Thermotolerant microalgae are excellent candidates for large-scale outdoor cultivation, especially in subtropical and tropical countries [57]. Dual $\mathrm{CO}_{2}$ and thermotolerant Chlorella sp. strains 283 and 359 were isolated from their original strain of Chlorella vulgaris ESP-31 by $N$-methyl- $N$-nitro- $N$-nitrosoguanidine (NTG) mutagenesis [58]. The microalgal strain grew well at $40{ }^{\circ} \mathrm{C}$ and had high biomass productivity, $0.73-0.89 \mathrm{~g} \mathrm{~L}^{-1} \mathrm{~d}^{-1}$, for a 4-day culture. 
Table 1. Growth performance and $\mathrm{CO}_{2}$ fixation efficiency of microalgal Chlorella with different tolerant characteristics.

\begin{tabular}{|c|c|c|c|c|c|c|c|c|}
\hline Tolerance Characteristics & Microalgae & Gas Aeration & Temp. $\left({ }^{\circ} \mathrm{C}\right)$ & $\begin{array}{l}\text { Maximum Biomass } \\
\text { Conc. }\left(\mathrm{g} \mathrm{L}^{-1}\right)\end{array}$ & $\begin{array}{l}\text { Biomass } \\
\text { Productivity } \\
\left(\mathrm{g} \mathrm{L}^{-1} \mathrm{~d}^{-1}\right)\end{array}$ & $\begin{array}{l}\mathrm{CO}_{2} \text { Fixation } \\
\text { Efficiency }^{1} \\
\left(\mathrm{~g} \mathrm{~L}^{-1} \mathrm{~d}^{-1}\right)\end{array}$ & Country $^{2}$ & References \\
\hline \multirow{7}{*}{ High- $\mathrm{CO}_{2}$ tolerant } & \multirow{2}{*}{ Chlorella sp. MTF-15 } & Flue gas 4 & \multirow[t]{2}{*}{26} & 2.52 & 0.515 & 0.942 & \multirow[t]{2}{*}{ TW } & \multirow[t]{2}{*}{ [48] } \\
\hline & & $10 \% \mathrm{CO}_{2}$ & & 3.22 & 0.293 & 0.536 & & \\
\hline & \multirow[t]{2}{*}{ Chlorella sp. AE20 } & $20 \% \mathrm{CO}_{2}$ & \multirow[t]{2}{*}{28} & 3.13 & 0.285 & 0.522 & \multirow{2}{*}{$\mathrm{CN}$} & \multirow[t]{2}{*}{ [59] } \\
\hline & & $30 \% \mathrm{CO}_{2}$ & & 3.02 & 0.275 & 0.503 & & \\
\hline & \multirow{3}{*}{$\begin{array}{l}\text { Chlorella vulgaris } \\
\text { NIOCCV }\end{array}$} & $5 \% \mathrm{CO}_{2}$ & \multirow{3}{*}{28} & 0.674 & 0.111 & 0.203 & \multirow{3}{*}{ IN } & \multirow{3}{*}{ [60] } \\
\hline & & $10 \% \mathrm{CO}_{2}$ & & 1.58 & 0.265 & 0.485 & & \\
\hline & & $20 \% \mathrm{CO}_{2}$ & & 0.976 & 0.163 & 0.298 & & \\
\hline $\mathrm{CO}_{2}$ tolerant & Chlorella sp. GD & Boiler flue gas ${ }^{3}$ & 26 & 6.54 & 0.892 & 1.632 & TW & [49] \\
\hline High- $\mathrm{CO}_{2}$ tolerant & Chlorella sp. LAMB 31 & $40 \% \mathrm{CO}_{2}$ & 26 & $\sim 0.9$ & 0.079 & 0.144 & $\mathrm{CN}$ & [15] \\
\hline $\begin{array}{l}\text { High- } \mathrm{CO}_{2} \text { and } \\
\text { thermotolerant }\end{array}$ & $\begin{array}{l}\text { Chlorella vulgaris ESP-31, } \\
283 \text { and } 359\end{array}$ & $\begin{array}{l}\text { Simulated flue gas } \\
\left(25 \% \mathrm{CO}_{2}, 80-90 \mathrm{ppm}\right. \\
\left.\mathrm{SO}_{2}, 90-100 \mathrm{ppm} \mathrm{NO}\right)\end{array}$ & 40 & $1.91(283) / 1.99$ (359) & $0.73(283) / 0.89$ (359) & $1.336(283) / 1.629(359)$ & TW & [58] \\
\hline $\begin{array}{l}\text { Alkali-tolerant } \\
\text { (pH 6-10) }\end{array}$ & Chlorella sp. AT1 & $10 \% \mathrm{CO}_{2}$ & 26 & 5.08 & 1.010 & 1.848 & TW & {$[62]$} \\
\hline \multirow{2}{*}{ Alkali-tolerant $(\mathrm{pH}>10)$} & Chlorella sorokiniana & Air & 20 & 0.9 & 0.059 & 0.108 & \multirow{2}{*}{ US } & [51] \\
\hline & SLA-04 & Air & $20-25$ & 0.74 & 0.046 & 0.078 & & [52] \\
\hline \multirow{6}{*}{ Thermotolerant } & Chlorella pyrenoidosa M18 & Air & 37 & 4.65 & 0.931 & 1.702 & IN & {$[54]$} \\
\hline & Chlorella sp. M4 & $6 \% \mathrm{CO}_{2}$ & 40 & 4.2 & 1.05 & 1.922 & TW & [55] \\
\hline & Chlorella pyrenoidosa M18 & Air & 45 & 1.69 & 0.338 & 0.619 & IN & [57] \\
\hline & \multirow{3}{*}{ Chlorella sorokiniana } & $10 \% \mathrm{CO}_{2}$ & & 1.16 & 0.232 & 0.425 & \multirow{3}{*}{ IN } & \multirow{3}{*}{ [56] } \\
\hline & & $15 \% \mathrm{CO}_{2}$ & 37 & 1.05 & 0.211 & 0.384 & & \\
\hline & & $5 \% \mathrm{CO}_{2}$ and $80 \mathrm{ppm} \mathrm{NO}$ & & 1.27 & 0.254 & 0.465 & & \\
\hline
\end{tabular}

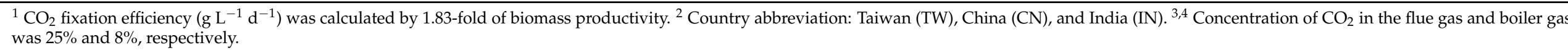




\section{2. $\mathrm{CO}_{2}$ from Flue Gas}

Flue gas is the main source of $\mathrm{CO}_{2}$ emissions on Earth. $\mathrm{CO}_{2}$ in flue gas has been used as a carbon source for microalgae cultivation in most studies (Table 2). However, $\mathrm{CO}_{2}$ fixation by microalgae still has many problems that need to be overcome. For example, high- $\mathrm{CO}_{2}$ tolerance in microalgae is insufficient and directly discharges flue gas into microalgal culture ponds, which might lead to rapid changes in the $\mathrm{pH}$ of the culture broth $[48,63,64]$. When microalgae cannot adapt to extreme culture conditions, death of the microalgae will occur. Therefore, it is necessary to screen microalgae for $\mathrm{pH}$ tolerance. In general, the main component of flue gas is $\mathrm{CO}_{2}$, which presents a variety of $\mathrm{CO}_{2}$ concentrations, depending on the fuel source and the design of the plant. Chlorella sp. MTF-15 was cultured with flue gas aeration from a hot stove $\left(26 \% \mathrm{CO}_{2}\right)$, coke oven $\left(25 \% \mathrm{CO}_{2}\right)$, or power plant $\left(24 \% \mathrm{CO}_{2}\right)$ at the China Steel Corporation, the largest steel plant in Taiwan. The biomass productivity of the microalgae cultured with flue gases from coke ovens, hot stoves, and power plants was $0.515,0.314$, and $0.342 \mathrm{~g} \mathrm{~L}^{-1} \mathrm{~d}^{-1}$, respectively [48]. Chlorella sp. was cultured in medium, with a controlled $\mathrm{pH}$ of 6 , by aerating with synthetic flue gas $\left(30 \% \mathrm{CO}_{2}\right)$ obtained from the African Oxygen Company in South Africa, and the maximum biomass concentration and biomass productivity were $3.42 \mathrm{~g} \mathrm{~L}^{-1}$ and $0.145 \mathrm{~g} \mathrm{~L}^{-1} \mathrm{~d}^{-1}$, respectively [40]. When Chlorella sorokiniana was aerated with flue gas $\left(16 \% \mathrm{CO}_{2}\right)$ from the oil-producing industry of India, the maximum $\mathrm{CO}_{2}$ sequestration was $3.07 \mathrm{~g} \mathrm{~L}^{-1}$ [65]. The maximum biomass concentration and biomass productivity of Chlorella sp. KR-1 aerated with flue gas from a coal-burning power plant in Korea were $2.81 \mathrm{~g} \mathrm{~L}^{-1}$ and $0.561 \mathrm{~g} \mathrm{~L}^{-1} \mathrm{~d}^{-1}$, respectively, and the $\mathrm{CO}_{2}$ removal efficiency was approximately $13 \%$ [66]. The maximum specific growth rate and biomass concentration of Chlorella fusca LEB111 aerated flue gas $\left(10 \% \mathrm{CO}_{2}\right)$ from coal power plants in Brazil were $0.181 \mathrm{~d}^{-1}$ and $1.24 \mathrm{~g} \mathrm{~L}^{-1}$, respectively [67]. The efficient biomitigation of $\mathrm{CO}_{2}(12-15 \%), \mathrm{NO}_{x}(0.01-0.08 \%)$, and $\mathrm{SO}_{\mathrm{x}}(0.006-0.06 \%)$ of flue gas from a power plant was obtained by the cultivation of Chlorella vulgaris $[68,69]$. The biomass concentration and amounts of $\mathrm{CO}_{2}$ sequestration of Chlorella sp. aerated with flue gas produced from the burning of coal were $1.92 \mathrm{~g} \mathrm{~L}^{-1}$ and $0.974 \mathrm{~g} \mathrm{~L}^{-1}$, respectively [70]. When integrated with sewage and flue gas in microalgal cultivation, the biomass concentration and $\mathrm{CO}_{2}$ removal efficiency of Chlorella vulgaris aerated with a coal-burning boiler $\left(6 \% \mathrm{CO}_{2}\right)$ in India were $1.72 \mathrm{~g} \mathrm{~L}^{-1}$ and $90 \%$, respectively [71]. A microalga Chlorella sp. Cv could tolerate the full-simulated flue gas, $10 \% \mathrm{CO}_{2}+200 \mathrm{ppm} \mathrm{NO}+100 \mathrm{ppm} \mathrm{SO}$. Under optimal conditions, the microalga could tolerate the simulated flue gas, and the maximum specific growth rate was $0.9824 \mathrm{~d}^{-1}$ [72]. It was proposed that the upregulation of several genes related to photosynthesis, oxidative phosphorylation, $\mathrm{CO}_{2}$ fixation, sulfur metabolism, and nitrogen metabolism was beneficial for the evolved microalga strain to tolerate the simulated flue gas [64]. Countries with high dependence on coal, such as China and India, are also actively engaged in $\mathrm{CO}_{2}$ carbon reduction research, using $\mathrm{CO}_{2}$ from the exhaust gas in microalgal cultivation to achieve carbon reduction, and use the produced microalgae biomass as a feedstock of biofuels. It has the opportunity to achieve economic and environmental sustainability by integrating the $\mathrm{CO}_{2}$ reutilization of exhaust gas and the effective development of biofuels. 
Table 2. Growth, $\mathrm{CO}_{2}$ fixation efficiency, and lipid productivity of the microalgae Chlorella cultures using flue gas.

\begin{tabular}{|c|c|c|c|c|c|c|c|c|}
\hline Microalgae & Flue Gas Source & $\mathrm{CO}_{2}(\%)$ & $\begin{array}{c}\text { Biomass } \\
\text { Productivity } \\
\left(\mathrm{g} \mathrm{L}^{-1} \mathrm{~d}^{-1}\right)\end{array}$ & $\begin{array}{c}\mathrm{CO}_{2} \text { Fixation } \\
\text { Efficiency } \\
\left(\mathrm{g} \mathrm{L}^{-1} \mathrm{~d}^{-1}\right)\end{array}$ & Lipid (\%) & $\begin{array}{c}\text { Lipid } \\
\text { Productivity }^{2} \\
\left(\mathrm{~g} \mathrm{~L}^{-1} \mathrm{~d}^{-1}\right)\end{array}$ & Country ${ }^{3}$ & References \\
\hline \multirow{5}{*}{ Chlorella sp. MTF-15 } & Coke oven & 13 & 0.528 & 0.966 & 21.5 & 0.614 & \multirow{5}{*}{ TW } & \multirow{5}{*}{ [48] } \\
\hline & & 13 & 0.449 & 0.822 & 33.8 & 0.866 & & \\
\hline & Hot stove & 26 & 0.314 & 0.575 & 35.2 & 0.591 & & \\
\hline & \multirow{2}{*}{ Power plant } & 12 & 0.423 & 0.774 & 36.3 & 0.792 & & \\
\hline & & 24 & 0.342 & 0.626 & 41.6 & 0.633 & & \\
\hline Chlorella sp. KR-1 & Coal-fired flue gas & 13 & 0.561 & 1.027 & 29.9 & 0.168 & $\mathrm{KR}$ & {$[66]$} \\
\hline Chlorella sp. & Coal burning & 5 & 0.273 & 0.500 & 8.69 & 0.024 & IN & [70] \\
\hline Chlorella fusca LEB 111 & Coal power plant & 10 & 0.111 & 0.203 & 15.5 & 0.017 & $\mathrm{BR}$ & [67] \\
\hline Chlorella vulgaris & Coal burning boiler & 6 & 0.312 & 0.571 & 23.2 & 0.074 & IN & [71] \\
\hline Chlorella sp. GD & Boiler flue gas & 8 & 1.296 & 2.372 & 21.7 & 0.214 & TW & [49] \\
\hline Chlorella sp. & Flue gas & 30 & 0.145 & 0.265 & 24.7 & 0.036 & $\mathrm{ZA}$ & [40] \\
\hline Chlorella sp. Cv & Simulated flue gas & 15 & 0.53 & 0.969 & ND & ND & $\mathrm{CN}$ & [64] \\
\hline Chlorella vulgaris & Power plant & 12 & 0.502 & 0.919 & 40.1 & 0.201 & ES & [68] \\
\hline Chlorella sp. C2 & Power plant & 3 & 0.314 & 0.575 & 31.5 & 0.099 & $\mathrm{CN}$ & [41] \\
\hline
\end{tabular}

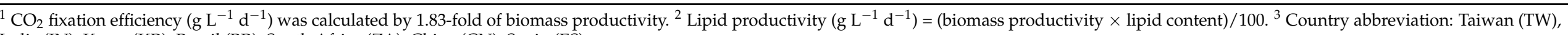
India (IN), Korea (KR), Brazil (BR), South Africa (ZA), China (CN), Spain (ES). 


\subsection{Nutrients from Wastewater}

In 2015, the United Nations World Water Development Report noted that the available freshwater resources globally will decrease by $40 \%$ by 2030 . However, more than $80 \%$ of the world's wastewater is discharged into the environment without treatment. The management model for wastewater should be changed from "treatment and disposal" to "reuse, recycle, and resource recovery". Therefore, the use of wastewater for microalgae cultivation is a technological development trend $[43,73,74]$. The source of wastewater can be mainly divided into three categories: agricultural, municipal wastewater, and industrial wastewater. As illustrated in Table 3, the growth performance and biomass productivity of microalgae cultured in different types of wastewater were different because the contents of COD, total nitrogen (TN), total phosphorus (TP), and specific inorganic substances in wastewater were obviously different $[25,44,49,75]$.

\subsubsection{Agriculture Wastewater}

The main source of agricultural wastewater was large livestock and poultry operations, and the main components in this wastewater were ammonium and organic nitrogen, which are good for microalgal growth. Piggery wastewater is commonly used in microalgal cultivation because this wastewater is rich in nutrient sources [76-80]. Additionally, aquaculture is a fast-growing industry because it has significantly increased the global demand for fish and seafood. Novel aquaculture systems incorporating wastewater treatment and effluent reuse have been rapidly developed for compliant wastewater discharge. Although the nutrient content of aquaculture wastewater is significantly lower than that of piggery wastewater, the content of pathogenic microorganisms and heavy metals contained in aquaculture wastewater is relatively low $[81,82]$. Therefore, aquaculture wastewater can be used as a large amount of water needed for microalgal cultivation, and the resulting microalgae biomass can be applied not only to a feedstock of biofuels, but also to animal additives or feed, which is a more minimal biosafety issue [49]. In Taiwan, most livestock wastewater is produced from pig farming. Therefore, it can be seen that the state has actively invested in research on the treatment of piggery wastewater. The raw piggery wastewater without pre-treatment could also be applied in microalgal cultivation. The produced microalgal biomass has about $20 \%$ lipids and is suitable for use as a feedstock of biodiesel $[25,49,77,83]$.

\subsubsection{Municipal Wastewater}

At present, a large amount of municipal wastewater is being produced due to an increase in urban population growth. The composition of municipal wastewater varies greatly because of the substances from various families, businesses, and institutions. For example, the COD and TN in a municipal sludge digestate were $2175 \mathrm{mg} \mathrm{L}^{-1}$ and $840 \mathrm{mg} \mathrm{L}^{-1}$, and $164 \mathrm{mg} \mathrm{L}^{-1}$ and $43.2 \mathrm{mg} \mathrm{L}^{-1}$ [84], in municipalities with reserve osmosis concentrate [85], respectively. Generally, the COD, TN, and TP utilization efficiencies of municipal wastewater in microalgal Chlorella cultivation were approximately $85-100 \%, 80-100 \%$, and $90-100 \%$, respectively (Table 3). However, growth and biomass productivity are low because municipal wastewater lacks nutrients for microalgae utilization [86-88]. Research on the reutilization of municipal wastewater in microalgae cultivation is commonly seen in many countries, such as United Kingdom (GB), USA (US), Australia (AU), etc. Due to the difference in the compositions of wastewater, to apply the technology of microalgal cultivation to cities, the culture process needs to be modified depending on the region to achieve stable growth of microalgae, and further, to achieve the dual advantages of wastewater purification and $\mathrm{CO}_{2}$ reduction.

\subsubsection{Industrial Wastewater}

Some small- and medium-sized enterprises and informal industries often discharge wastewater into municipal pipelines or directly discharge it into the environment. Compared with the hazards caused by agricultural and municipal wastewater, industrial 
wastewater could be more harmful to water resources and the environment due to the contents of toxic heavy metal components. There are also studies on diluting the wastewater to reduce the sensitivity of the microalgal strain towards the toxicity of wastewater, and increase the wastewater utilization effectivity to obtain the microalgal growth $[25,89]$. However, wastewater from food processing is usually regarded as a safety resource and is suitable for the production of microalgal biomass for feed or food uses [90]. Because the sources of industrial wastewater were obviously different, the ranges of COD, TN, and TP utilization efficiencies of industrial wastewater in microalgal Chlorella cultivation were approximately $25-95 \%, 30-100 \%$, and $50-100 \%$, respectively [84,91-93] (Table 3 ). The $\mathrm{COD}, \mathrm{TN}$, and TP contents of the food industry wastewater is relatively rich, which is very suitable for use as nutrient sources for microalgae cultivation. Therefore, the better growth of microalgae can be obtained. However, the problem of bacterial contamination is more likely to occur because of the higher nutrient contents. This will affect the long-term stable performance of the microalgal cultivation technology.

Table 3. Biomass and lipid production and productivity of the microalgae Chlorella cultures using wastewater.

\begin{tabular}{|c|c|c|c|c|c|c|c|c|c|c|}
\hline $\begin{array}{l}\text { Wastewater } \\
\text { Source }\end{array}$ & Microalgae & $\underset{\left(\mathrm{mg} \mathrm{L}^{-1}\right)}{\mathrm{COD}^{1}}$ & $\begin{array}{c}\mathrm{TN}^{1} \\
\left(\mathrm{mg} \mathrm{L}^{-1}\right)\end{array}$ & $\begin{array}{c}\mathrm{TP}^{1} \\
\left(\mathrm{mg} \mathrm{L}^{-1}\right)\end{array}$ & $\begin{array}{l}\text { Biomass } \\
\text { Productivity } \\
\left(\mathrm{g} \mathrm{L}^{-1} \mathrm{~d}^{-1}\right)\end{array}$ & $\begin{array}{c}\mathrm{CO}_{2} \\
\text { Fixation } \\
\text { Efficiency } \\
\left(\mathrm{g} \mathrm{L}^{-1} \mathrm{~d}^{-1}\right)\end{array}$ & $\underset{(\%)}{\text { Lipid }}$ & $\begin{array}{l}\text { Lipid Pro- } \\
\text { ductivity } \\
\left(\mathrm{g} \mathrm{L}^{-1} \mathrm{~d}^{-1}\right)\end{array}$ & Country ${ }^{4}$ & References \\
\hline \multicolumn{11}{|c|}{ Agricultural wastewater } \\
\hline Raw dairy & Chlorella sp. & 2593 & 283 & 116 & 0.261 & 0.478 & - & - & $\mathrm{CN}$ & [76] \\
\hline $\begin{array}{l}\text { Anaerobically } \\
\text { treated piggery }\end{array}$ & $\begin{array}{l}\text { Chlorella vulgaris } \\
\text { CY5 }\end{array}$ & 377 & 287 & 28 & 0.281 & 0.514 & 19.6 & 0.055 & TW & [77] \\
\hline $\begin{array}{c}\text { Piggery } \\
\text { Aquaculture }\end{array}$ & Chlorella sp. GD & $\begin{array}{l}490 \\
121\end{array}$ & $\begin{array}{l}550 \\
234\end{array}$ & $\begin{array}{l}20 \\
15\end{array}$ & $\begin{array}{l}0.681 \\
1.296\end{array}$ & $\begin{array}{l}1.246 \\
2.372\end{array}$ & $\begin{array}{l}21.8 \\
21.3\end{array}$ & $\begin{array}{l}0.148 \\
0.276\end{array}$ & $\begin{array}{l}\text { TW } \\
\text { TW }\end{array}$ & $\begin{array}{l}{[25]} \\
{[49]}\end{array}$ \\
\hline Swine & $\begin{array}{l}\text { Chlorella vulgaris } \\
\text { UTEX-265 }\end{array}$ & 1481 & 307 & 4.3 & 0.247 & 0.452 & 27.1 & 0.067 & $\mathrm{KR}$ & [78] \\
\hline Piggery & $\begin{array}{l}\text { Chlorella sorokiniana } \\
\text { AK-1 }\end{array}$ & $1500-4500$ & $500-700$ & $150-250$ & 0.55 & 1.006 & - & - & TW & [83] \\
\hline \multicolumn{11}{|c|}{ Municipal wastewater } \\
\hline Centrate & $\begin{array}{c}\text { Chlorella sorokiniana } \\
\text { UTEX1230 }\end{array}$ & - & 53 & 9.4 & 0.083 & 0.152 & 9.4 & 0.008 & GB & {$[86]$} \\
\hline Domestic & $\begin{array}{l}\text { Chlorella vulgaris } \\
\text { Chlorella } \\
\text { minutissima }\end{array}$ & 142 & 56 & 9 & $\begin{array}{l}0.054 \\
0.049\end{array}$ & $\begin{array}{l}0.099 \\
0.090\end{array}$ & $\begin{array}{l}21.5 \\
22.9\end{array}$ & $\begin{array}{l}0.012 \\
0.011\end{array}$ & US & [94] \\
\hline Municipal & $\begin{array}{l}\text { Chlorella vulgaris } \\
\text { SAG 211-11b }\end{array}$ & 2175 & 840 & 10 & 0.144 & 0.264 & 23 & 0.033 & FI & [84] \\
\hline Secondary & $\begin{array}{l}\text { Chlorella vulgaris } \\
\text { UTEX } 26 \\
\text { Chlorella vulgaris } \\
\text { CICESE }\end{array}$ & 131 & 112 & 35 & $\begin{array}{l}0.078 \\
0.105\end{array}$ & $\begin{array}{l}0.143 \\
0.192\end{array}$ & $\begin{array}{l}8.7 \\
20.2\end{array}$ & $\begin{array}{l}0.021 \\
0.025\end{array}$ & MX & [87] \\
\hline $\begin{array}{l}\text { Centrate } \\
\text { Municipal }\end{array}$ & Chlorella vulgaris & 513 & 803 & 32 & 0.071 & 0.130 & 29.6 & 0.021 & $\mathrm{CN}$ & [88] \\
\hline $\begin{array}{l}\text { (osmosis } \\
\text { concentrate) } \\
\text { Industria }\end{array}$ & $\begin{array}{l}\text { Chlorella vulgaris } \\
\text { wastewater }\end{array}$ & 164 & 43.2 & 13.1 & 0.32 & 0.585 & - & - & $\mathrm{AU}$ & [85] \\
\hline Meat processing & $\begin{array}{l}\text { Chlorella sp. } \\
\text { UM6151 }\end{array}$ & 2100 & 212 & 54 & 0.171 & 0.313 & 17.5 & 0.029 & US & {$[90]$} \\
\hline Food & Chlorella vulgaris & 341 & - & - & 0.207 & 0.379 & 31 & 0.064 & $\mathrm{CN}$ & [91] \\
\hline Pulp and paper & $\begin{array}{l}\text { Chlorella vulgaris } \\
\text { SAG } 211-11 \mathrm{~b}\end{array}$ & 905 & 350 & 28 & 0.208 & 0.381 & 21.7 & 0.045 & FI & {$[84]$} \\
\hline $\begin{array}{l}\text { Alcohol and } \\
\text { starch processing }\end{array}$ & Chlorella pyrenoidosa & 3599 & 334 & 39 & 0.376 & 0.688 & 19.7 & 0.074 & $\mathrm{CN}$ & [92] \\
\hline Tofu whey & $\begin{array}{c}\text { Chlorella pyrenoidosa } \\
\text { FACHB-9 }\end{array}$ & - & 592 & 49 & 0.283 & 0.518 & 17.5 & 0.049 & $\mathrm{CN}$ & [93] \\
\hline
\end{tabular}

${ }^{1} \mathrm{COD}, \mathrm{TN}$, and TP: chemical oxygen demand, total nitrogen, and total phosphorus of wastewater. ${ }^{2} \mathrm{CO}_{2}$ fixation efficiency $\left(\mathrm{g} \mathrm{L}^{-1} \mathrm{~d}^{-1}\right)$ was calculated by 1.83 -fold of biomass productivity. ${ }^{3}$ Lipid productivity $\left(\mathrm{g} \mathrm{L}^{-1} \mathrm{~d}^{-1}\right)=$ (biomass productivity $\times$ lipid content)/100. ${ }^{4}$ Country abbreviation: China (CN), Taiwan (TW), Korea (KR), United Kingdom (GB), USA (US), Finland (FI), Mexico (MX), Australia (AU). -: Data not shown.

\subsection{Light}

Because of photosynthesis for microalgal growth, light is the most important parameter in microalgal cultivation. Lighting in microalgal cultivation contains two main factors: light intensity and the wavelength of light. In general, the growth rate of microalgae can be greatly increased along with an increase in light intensity; however, when the light intensity exceeds the saturation light that can be tolerated by microalgae, the growth rate of microalgae will be significantly decreased [95]. Therefore, to achieve the maximum growth rate of microalgae, the light intensity is usually controlled to "light saturation". Because microalgae itself will 
block light from passing, the light intensity decreases sharply with distance through the surface, causing a decrease in the growth rate of microalgae [96]. Under $400-\mu \mathrm{mol} \mathrm{m}^{-2} \mathrm{~s}^{-1}$ specific light intensity, the microalgal biomass productivity of a Chlorella sp. strain in photobioreactors (PBRs) was approximately 2-fold higher at $0.518 \mathrm{~g} \mathrm{~L}^{-1} \mathrm{~d}^{-1}$ than that grown in outdoor raceway open ponds [24]. The growth of microalgae Chlorella increased by continuous illumination using a light-emitting diode (LED) at the optimal light intensity without a shortage in light energy $[97,98]$. The incremental light intensity strategy was also an efficient way to improve microalgae growth because photoinhibition at the initial culture phase and insufficient light intensity at the latter culture phase could be avoided [99]. In terms of the wavelength of light, a wavelength range of 400 to $750 \mathrm{~nm}$ is absorbed during photosynthesis by most microalgae. The light source for the autotrophic cultivation of Chlorella vulgaris was investigated, and the results showed that red LED light (630-665 nm) resulted in small cells with active divisions, while blue light (430-465 nm) LED illumination led to a significant increase in cell size [100]. The mixed LED light wavelength with red and blue LED light (e.g., red:blue is 5:5) also affects and enhances microalgal growth, including Scenedesmus obliquus, Neochloris oleoabundans, and Chlorella vulgaris [101].

\section{5. $p H$}

The $\mathrm{pH}$ of culture broth affects the enzyme activity related to the metabolism of microalgae and the ion absorption efficiency of microalgae, which in turn affects the growth and carbon fixation efficiency of microalgae $[50,102]$. The optimal $\mathrm{pH}$ for growth varies among microalgal species, and in general, the optimum $\mathrm{pH}$ is neutral for most microalgae [103]. Flue gas usually contains high concentrations of $\mathrm{CO}_{2}, \mathrm{NO}_{\mathrm{x}}$, and $\mathrm{SO}_{2}$ [48]. When microalgae were directly aerated with flue gas containing $10-30 \% \mathrm{CO}_{2}$, the $\mathrm{pH}$ of the culture broth might be reduced to 5.5 [7]. When the microalgae were aerated with flue gas containing $\mathrm{SO}_{2}$ at 100 to $250 \mathrm{ppm}$, the $\mathrm{pH}$ of the culture broth decreased to $\mathrm{pH} 2.5$ to 3.5 to generate bisulfite $\left(\mathrm{HSO}_{3}{ }^{-}\right)$, sulfite $\left(\mathrm{SO}_{3}{ }^{2-}\right)$, and sulfate $\left(\mathrm{SO}_{4}{ }^{2-}\right)$ [7]. If the flue gas is directly aerated into the culture broth of microalgae without dilution, the excess $\mathrm{CO}_{2}$ of flue gas will be discharged back to the atmosphere. To reduce the $\mathrm{CO}_{2}$ discharged back to the atmosphere, the $\mathrm{CO}_{2}$ captured from flue gas aerated into alkaline medium is easily converted into $\mathrm{HCO}_{3}{ }^{-}$, which is dissolved in water and used for microalgal growth. The solubility of $\mathrm{CO}_{2}$ in water is low, but the $\mathrm{CO}_{2}$ content in the culture broth can be increased under alkaline conditions to further increase the $\mathrm{CO}_{2}$ utilization efficiency of microalgae [104]. In addition, gradually increasing the $\mathrm{pH}$ in a microalgal culture is desirable for reducing microbial diversity and is good for outdoor cultivation of microalgae [105].

\subsection{Temperature}

The optimal temperature range for microalgae growth is generally $15-26{ }^{\circ} \mathrm{C}$ [106]. Ribulose-1,5-bisphosphate carboxylase/oxygenase (Rubisco) activity may be a primary site of damage by elevated temperature to cause a decrease in photosynthesis efficiency [107]. In contrast, there was not only a decrease in the metabolic rate of microalgae, but also a decrease in $\mathrm{CO}_{2}$ solubility in culture broth. Therefore, the optimal temperature for growth varies among microalgal species. The temperature of the flue gas will generally be as high as $120^{\circ} \mathrm{C}$ or even higher [48]. Flue gas usually needs cooling to be aerated into the culture broth because the temperature of flue gas is too high. If the thermal-tolerant potential of microalgae is good, the cost of flue gas cooling can be reduced. In addition, when sunlight is used outdoors as a light source, the temperature of the culture broth easily changes with the surrounding environment. Béchet et al. [108] indicated that 18,000 GJ year ${ }^{-1} \mathrm{ha}^{-1}$ of heat energy must be removed to maintain the broth temperature of column PBRs at or below $25^{\circ} \mathrm{C}$. Considering the cost of temperature control, thermotolerant microalgal strains are needed, especially in large-scale outdoor cultivation. When Chlorella sorokiniana was cultivated in outdoor 51-L column PBRs, the culture broth temperature reached $41^{\circ} \mathrm{C}$ 
without growth inhibition [109], and similar results showed better growth performance under uncontrolled temperature in outdoor conditions [55,57].

\subsection{Microalgal Cultivation System}

Open (raceway) ponds and PBRs of microalgal cultivation systems are usually-and primarily-adopted. Studies on $\mathrm{CO}_{2}$ fixation by microalgae used in open ponds and PBRs are outlined in Table 4. It has been reported that microalgal biomass production produced from open ponds is more efficient than $90 \%$ of worldwide biomass production [110]. The most prominent features of open ponds include simple construction, low cost and easy operation [111,112]. However, disadvantages of open ponds are also obvious, such as a large footprint, difficulties in operation control, unstable culture conditions, high evaporation loss, easy contamination, and the decay of light intensity with medium depth. Compared with open ponds, PBRs have many advantages, such as the most efficient mixing, the best growth conditions, high volumetric mass transfer rates, low risk of contamination, lowest losses of $\mathrm{CO}_{2}$, low shear stress and relatively low energy consumption $[18,75,113]$. However, the limitations of PBRs are construction cost and scale-up [114]. Overcoming the above shortcomings of cultivation systems is a future research direction for developing advanced cultivation systems. The two cultivation systems still have many challenges in practical operation [115]. Closed cultivation systems, e.g., PBRs, are still not widely applied in industry because the operation cost and construction costs of the systems are too high despite the high microalgal biomass productivity [116]. To solve the limitations of large-scale outdoor microalgae cultivation systems, from an engineering perspective, how to increase the efficiency of gas aeration and mixing should be considered. Low cost and energy consumption can both be achieved by the design of air mixing with flue gas $\mathrm{CO}_{2}$ aeration to improve microalgal growth by sufficient $\mathrm{CO}_{2}$ utilization. Therefore, outdoor large-scale microalgae cultivation systems can become closer to the industrialization process and commercial application by improving the efficiency of gas aeration and mixing. Suitable microalgal cultivation systems usually depend on factors such as cost, $\mathrm{CO}_{2}$ capture source, nutrient sources, and the type of target products. At present, most studies on $\mathrm{CO}_{2}$ fixation by microalgae are used in open ponds or PBRs, and few studies have integrated both microalgal cultivation systems to enhance biomass productivity $[24,117]$. In our previous study [24], an efficient PBRs/raceway circulating (PsRC) system integrated with the advantages of PBRs and paddlewheel-driven raceway ponds had great potential for the mass cultivation of microalgae. The total amount of $\mathrm{CO}_{2}$ fixation of the PsRC system was approximately $1.2 \mathrm{~kg} \mathrm{~d}^{-1}$ with $50 \% \mathrm{CO}_{2}$ utilization efficiency, as simultaneous microalgal biomass production and $\mathrm{CO}_{2}$ fixation occurred by cultivating alkali-tolerant Chlorella sp. AT1 with alkaline- $\mathrm{CO}_{2}$ capturing operation in the PsRC system. Long-term cultivation for 40 days in a novel membrane photobioreactor, the steadily growth of Chlorella vulgaris were obtained and the maximum removal efficiency of $\mathrm{CO}_{2}$ was $80 \%$. Because the self-forming dynamic membrane from microalgae was easy to harvest, the potential of achieving a sustainable $\mathrm{CO}_{2}$ fixation technology [118]. To investigate the carbon fixation effectivity of microalgae in outdoor cultivation, many studies have used the design of the cultivation system to scale up to pilot scale and industrial scale. The pilot scale is mainly used for research, because the expansion of the outdoor cultivation system may increase the cost of construction, the risk of microorganism pollution, and the release large amounts of $\mathrm{CO}_{2}$. In Table 4, the research in China and Taiwan has reached a ton scale, and it can be combined with waste gas for microalgae cultivation. The cultivation system combination the strategy of an increase of the $\mathrm{CO}_{2}$ content in the water for the microalgal growth and enhance the $\mathrm{CO}_{2}$ carbon fixation efficiency. One is to couple with spraying absorption tower to increase the $\mathrm{CO}_{2}$ content in the water [119], another is to use alkali-tolerant mutant strain combined with alkaline- $\mathrm{CO}_{2}$ capturing medium [24]. 
Table 4. Biomass productivity and $\mathrm{CO}_{2}$ fixation efficiency of microalgae Chlorella in different cultivation systems.

\begin{tabular}{|c|c|c|c|c|c|c|c|c|}
\hline Microalgae & Cultivation System & $\begin{array}{l}\text { Cultivation Scale } \\
\text { (L) }\end{array}$ & $\mathrm{CO}_{2}(\%)$ & $\begin{array}{l}\text { Maximum Biomass } \\
\text { Conc. }\left(\mathrm{g} \mathrm{L}^{-1}\right)\end{array}$ & $\begin{array}{l}\text { Biomass } \\
\text { Productivity } \\
\left(\mathrm{g} \mathrm{L}^{-1} \mathbf{d}^{-1}\right)\end{array}$ & $\begin{array}{l}\mathrm{CO}_{2} \text { Fixation } \\
\text { Efficiency }^{1} \\
\left(\mathrm{~g} \mathrm{~L}^{-1} \mathrm{~d}^{-1}\right)\end{array}$ & Country ${ }^{2}$ & References \\
\hline \multirow{3}{*}{ Chlorella sp. MTF-15 } & \multirow{2}{*}{ Column-type PBR } & \multirow{3}{*}{$\begin{array}{c}1 \\
1200\end{array}$} & \multirow{2}{*}{12.5 (1/2 flue gas) } & 2.855 & 0.528 & 0.966 & \multirow{2}{*}{ TW } & \multirow{3}{*}{ [48] } \\
\hline & & & & 1.555 & 0.197 & 0.361 & & \\
\hline & Porous air-lift PBR & & \multirow{3}{*}{0.03 (air) } & 0.095 & 0.004 & 0.174 & \multirow{3}{*}{ HK } & \\
\hline \multirow[t]{2}{*}{ Chlorella vulgaris } & Loop air-lift PBR & \multirow{2}{*}{16} & & 0.126 & 0.007 & 0.231 & & \multirow{2}{*}{ [120] } \\
\hline & Bubbling PBR & & & 0.783 & 0.054 & 1.433 & & \\
\hline \multirow{2}{*}{ Chlorella sp. GD } & \multirow{2}{*}{ Column-type PBR } & \multirow[b]{2}{*}{1} & 2 & 4.813 & 0.870 & 1.592 & \multirow[b]{2}{*}{ TW } & [25] \\
\hline & & & 8 (boiler flue gas) & 4.921 & 1.296 & 2.333 & & [49] \\
\hline Chlorella vulgaris & Flat-plate PBR & 1.6 & 5 & 2.303 & 0.551 & 1.008 & $\mathrm{CN}$ & [95] \\
\hline Chlorella vulgaris & Bubble column PBR & 56 & 0.03 (air) & 0.962 & 0.043 & 0.079 & MY & [122] \\
\hline Chlorella pyrenoidosa & Open raceway pond & 8000 & 99.5 & 0.927 & 0.114 & 0.214 & $\mathrm{CN}$ & [119] \\
\hline Chlorella vulgaris & Coiled tubular tree PBR & 1.2 & 0.03 (air) & 0.552 & 0.084 & 0.153 & CA & [123] \\
\hline Chlorella sorokiniana & Flat panel PBR & 90 & 5 & 1.913 & 0.091 & 0.167 & US & [124] \\
\hline Chlorella vulgaris & Pilot-scale PBR & 150 & Without aeration & 2.211 & 0.198 & 0.362 & $\mathrm{CN}$ & [125] \\
\hline \multirow{5}{*}{ Chlorella sp. AT1 } & Column-type PBR & 1 & 10 & 7.372 & 1.011 & 1.851 & TW & [62] \\
\hline & \multirow{4}{*}{$\begin{array}{l}\text { PBRs/Raceway } \\
\text { circulating system }\end{array}$} & 288 & \multirow{4}{*}{2} & 2.561 & 0.321 & 0.588 & \multirow{4}{*}{ TW } & \multirow{4}{*}{ [24] } \\
\hline & & 528 & & 1.963 & 0.237 & 0.434 & & \\
\hline & & 1008 & & 1.052 & 0.107 & 0.195 & & \\
\hline & & 3600 & & 1.686 & 0.150 & 0.275 & & \\
\hline Chlorella sp. HS2 & Flat panel PBR & 2 & 1 & 3.811 & 0.543 & 1.021 & $\mathrm{KR}$ & [126] \\
\hline Chlorella vulgaris UTEX 26 & Raceway & 1100 & 0.03 (air) & 0.25 & $\begin{array}{l}20-26\left(\mathrm{~g} \mathrm{~m}^{-2} \mathrm{~d}^{-1} \text { for }\right. \\
65 \text { davs culture) }\end{array}$ & - & MX & {$[111]$} \\
\hline Chlorella pyrenoidosa PY-ZU1 & Pond-tubular hybrid PBR & $<5$ (a model system) & 15 & 2.3 & 0.770 & 1.409 & $\mathrm{CN}$ & [117] \\
\hline Chlorella vulgaris & $\begin{array}{c}\text { Raceway with } \\
\text { computational fluid } \\
\text { dynamics }\end{array}$ & +5 & $\begin{array}{l}50 \text { (mix with air and } \\
\text { pure } \mathrm{CO}_{2} \text { gas) }\end{array}$ & 5.2 & $\begin{array}{l}11.89\left(\mathrm{~g} \mathrm{~m}^{-2} \mathrm{~d}^{-1}\right. \\
14 \mathrm{~cm} \text { depth of } \\
\text { raceway })\end{array}$ & - & TW & [112] \\
\hline $\begin{array}{c}\text { Chlorella vulgaris CCAP } \\
211 / 11 \mathrm{~B}\end{array}$ & $\begin{array}{c}\text { Membrane } \\
\text { photobioreactor }\end{array}$ & 40 & 15 & 1.01 & 0.166 & 0.704 & IT & [118] \\
\hline
\end{tabular}

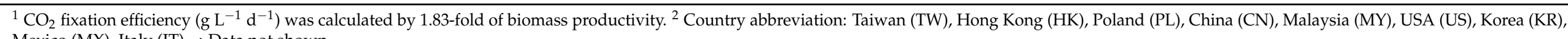
Mexico (MX), Italy (IT). -: Data not shown. 


\section{Biorefinery of Microalgal Biomass for Producing Biofuels and Byproducts}

Microalgae cultivation is the most efficient method for biological carbon reduction and biofuel production $[17,127]$. Microalgal biomass cannot only be used as a feedstock for biofuels, but also be applied to the development of foods, nutrient supplements, cosmetics, and feed additives for animals and aquaculture (Figure 2). In recent decades, many global studies on microalgae have begun, and are actively engaged in the development and application of novel microalgae technologies with potential for commercialization [128]. Many international companies and countries throughout the world have also actively engaged in microalgae biorefinery research. For example, using microalgae as a feedstock, microalgal lipids can be treated with transesterification to produce biodiesel and jet fuel. Microalgal biomass polysaccharides can produce biofuels and various chemicals after chemical refinery processes and fermentation, and microalgal proteins can be used as feed additives [26]. Microalgal biomass also contains high-value compounds, such as carotenoids, lutein, and astaxanthin. Many biorefinery processes have been actively developed to convert microalgal biomass into biofuel, syngas, and even high-value chemical and biological byproducts. Microalgae are not a bioenergy source of commercialization in the short-term due to the low price of fossil fuels. Therefore, increasing the economic value of microalgae has become an important part of the development of microalgae technology. At present, the main uses of high-value microalgae are health foods, food additives and animal feed additives [19]. The biomass produced by the utilization of wastewater and waste gas in microalgae cultivation is mainly used as biofuel for biosafety considerations. However, from the perspective of economic value, it is recommended to further extract more functional compounds from the microalgal biomass, such as carotenoids, develop diversified high-value products. The final microalgae residue can also be used for biochar, so that the microalgae carbon fixation technology will have the opportunity to be truly applied to the industry.

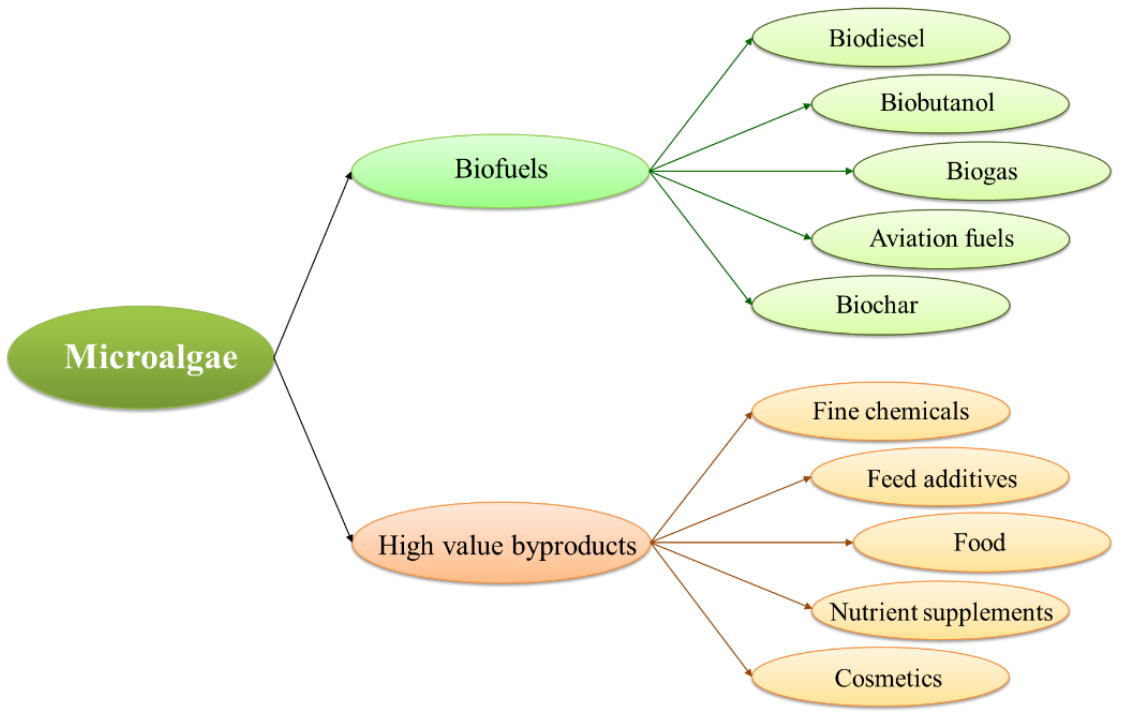

Figure 2. Biorefinery application of microalgal biomass on biofuels and high-value byproducts production.

\subsection{Biodiesel}

According to a 2017 report by Grand View Research, Inc., the global biodiesel market is expected to reach USD 54.8 billion by 2025. The market is expected to have a $7.3 \%$ compound annual growth rate (CAGR), owing to the increasing demand for biodiesel as a fuel in the automotive, marine, railway, and power generation industries. Biodiesel has become the mainstream biomass energy development and application in various countries worldwide due to its advantages of easy transportation, convenient storage, and direct application to current diesel engines [129]. At present, developed countries and developing countries are dedicated to an increase in biodiesel production. Therefore, countries around the world are still dedicated to the development of new feedstock for biodiesel production. 
Among various new feedstocks, microalgae have become feedstock for third-generation (3G) biodiesel because microalgae have a higher growth rate and utilization efficiency of solar energy than terrestrial oil-producing crops [130]. Microalgal oil production per unit of cultivated area is greater than that of other oil-producing crops [110]. The processing techniques of diesel from microalgal oil include pyrolysis and transesterification. However, when biodiesel is produced by pyrolysis, it is difficult to commercialize due to the consumption of a large amount of energy and the complexity of operation processes and produced products. Transesterification processing is the main processing for commercial biodiesel production because of its simple operation and low cost. In microalgae biorefineries, biodiesel development is the most frequently mentioned research topic due to fossil energy shortages. Therefore, several studies have investigated inexpensive and energy-efficient biodiesel obtained by integrating microalgae with flue gas aeration and wastewater reutilization $[25,49,60,131]$.

\subsection{Biobutanol}

Carbohydrates of microalgae can be converted into fermentable sugars through hydrolysis to produce bioethanol and biobutanol [132,133]. Among the potential liquid biofuels, biobutanol is especially promising due to its higher energy density, lower hygroscopy, and superior physical and chemical properties as a gasoline additive to replace bioethanol. In addition to being a biofuel, biobutanol can also be used as a solvent for industrial purposes [134]. However, approximately $60 \%$ of the total biobutanol production cost comes from the feedstock cost. Therefore, carbohydrate-rich and fast-growing microalgae are considered potential feedstocks for biobutanol production [133,134]. Therefore, microalgal biomass, which is rich in carbohydrates, serves as a good and inexpensive feedstock for acetone-butanol-ethanol (ABE) fermentation to produce biobutanol [135]. The biobutanol production via $\mathrm{ABE}$ fermentation using carbohydrate-rich microalgae Chlorella vulgaris JSC- 6 with $1 \% \mathrm{NaOH}$ pretreatment and $3 \% \mathrm{H}_{2} \mathrm{SO}_{4}$ hydrolysis was $13.1 \mathrm{~g} \mathrm{~L}^{-1}$ [136]. The highest biobutanol production by ABE fermentation using the resulting biomass of Chlorella sp. DEE006 was $6.23 \mathrm{~g} \mathrm{~L}^{-1}$ [137]. Wang et al. [133] used the carbohydrate-rich microalga Neochloris aquatica CL-M1 as a feedstock for butanol fermentation. Their results showed that the butanol concentration, yield, and productivity were $12.0 \mathrm{~g} \mathrm{~L}^{-1}, 0.60 \mathrm{~mol}$ $\mathrm{mol}^{-1}$ sugar, and $0.89 \mathrm{~g} \mathrm{~L}^{-1} \mathrm{~h}^{-1}$, respectively.

\subsection{Biogas}

Microalgal biomass can be used as substrates for anaerobic digestion to produce biogas. Biogas mainly consists of $50-70 \% \mathrm{CH}_{4}, 30-50 \% \mathrm{CO}_{2}$, and other trace amounts of nitrogen $\left(\mathrm{N}_{2}\right)$, ammonia $\left(\mathrm{NH}_{3}\right)$, and hydrogen sulfide $\left(\mathrm{H}_{2} \mathrm{~S}\right)$ gases $[138,139]$. The distribution of macromolecule profiles, mainly including proteins, lipids, and carbohydrates, affects the efficacy of biogas production and changes because of microalgae species and culture conditions [140]. Moreover, the practical biogas production of microalgal biomass is lower than the theoretical production due to the rigid cell wall of microalgae, $\mathrm{C}: \mathrm{N}$ ratio of microalgal biomass, and the conditions of anaerobic digestion [141]. When microalgae biomass was pretreated to break down the cell wall by pretreatment with heat, pressure, enzyme hydrolysis, microwave, and ultrasonication before anaerobic digestion, biogas production could be increased significantly [142,143]. Microalgal biomass could be used as a substrate and cosubstrate for biogas production [141]. A maximum production of approximately $240 \mathrm{~mL} \mathrm{CH}_{4(\mathrm{~g})}$ volatile solids ${ }^{-1}$ was obtained by the co-digestion of chicken manure and microalgae Chlorella 1067 [144]. When $\mathrm{CO}_{2}$ was generated in the biogas, the calorific value of the biogas was reduced due to the lower amount of $\mathrm{CH}_{4}$ [145]. Therefore, $\mathrm{CO}_{2}$ in biogas can be used for microalgae culture for biogas upgrading, i.e., increasing the $\mathrm{CH}_{4}$ concentration of biogas. Kao et al. [61] established an outdoor microalgae-incorporating culture system with a gas cycle-switching operation that could be efficiently used as a $\mathrm{CO}_{2}$ capture model for biogas upgrading. The concentration of $\mathrm{CH}_{4}$ could be increased from the original $70 \%$ to $87 \%$ by utilizing $\mathrm{CO}_{2}$ in desulfurized biogas produced from the anaerobic 
digestion of swine wastewater by an outdoor cultivation of Chlorella sp. MM-2 [146]. The maximum $\mathrm{CH}_{4}$ content of the co-digested treatment of Napier grass and cow farm slurry group for 45 days was increased to $64.4 \%$, which was 3.4-fold higher than that of the untreated group [147]. A new discovered process of direct interspecies electron transfer (DIET) can help to an increase of biogas production by promoting rapid electron donation and acceptance of microbes during the anaerobic digestion [148].

\subsection{Aviation Fuels}

Although microalgae biofuels are limited in the aviation industry [149], microalgaebased aviation fuels are considered a substitute to produce an efficient fuel. For example, United Airlines and Qantas have tried using blends of microalgal biofuel with up to $40 \%$ mixtures and have completed successful trials of the product. For some microalgae species, the free fatty acids in microalgae oil are nearly similar to those in crude petroleum. Aviation fuels are a complex mixture of a large number of hydrocarbons from C8 to C16 [150]. The conversion of microalgae oil into aviation fuel needs to reduce the number of carbon chains by catalytic processes because the carbon chains of microalgal oils are often C16 and C18 [151]. The catalytic process aims to modify the carbon molecules from microalgae oil to obtain the chemical structure or configuration known for aviation fuel [152].

\subsection{Biochar}

Biochar from agricultural crop, wood, animal manure, and microalgal biomass can be produced by thermochemical processes, such as pyrolysis, torrefaction, and hydrothermal carbonization [153]. Compared with the lignocellulosic biomass, it has a better chance of achieving the sustainable carbon reduction technology by microalgal biomass due to the lipid-rich characteristic [154]. The short-chain fatty acids (SCFAs) production was increased in the anaerobic fermentation of microalgae by applying the algae-derived biochar [155]. The high surface area of biochar BC-450 was made from the residue of marine Chlorella sp. after lipid and pigment extraction through ultrasonic extraction and pyrolysis. The removal efficiency of heavy metal including $\mathrm{Cr}(\mathrm{VI}), \mathrm{Zn}(\mathrm{II})$, and $\mathrm{Ni}(\mathrm{II})$, was in $84-99 \%$ by adsorbent of biochar BC-450 due to the higher surface area [156]. As a green adsorption material, microalgal-based biochar also is used in wastewater remediation [157]. The nutrient-rich biochar after wastewater treatment further can be applied as biofertilizer and used for soil amendment $[158,159]$. Although the large-scale application technology of biochar in soil amendments or biofertilizers is still under development, microalgae-based biochar is indeed a promising material for wastewater treatment, soil remediation, and gas storage and separation [160].

\subsection{Lactic Acid and Succinic Acid of Fine Chemicals}

When microalgae are rich in carbohydrates, microalgal biomass can be used for the fermentative production of fine chemicals, such as succinic acid and lactic acid [161-163]. Because lactic acid has both carboxyl and hydroxyl groups, it can be converted into many useful chemicals, such as pyruvic acid, lactate esters, 1,2-propanediol, and acrylic acid [164]. The fermentative lactic acid yield of Lactobacillus plantarum 23 using the acid hydrolysis of Chlorella sp. M4 was $0.43 \mathrm{~g}^{-1}$ microalgal biomass under anaerobic conditions for $24 \mathrm{~h}$ [55]. Succinic acid is used as an intermediate chemical for a wide range of applications, such as industrial, food, cosmetics, and pharmaceutical uses. According to the report of Markets and Markets in 2018, the global succinic acid market was estimated to be USD 132 million in 2018 and is projected to reach USD 183 million by 2023, at a CAGR of $6.8 \%$. The biobased succinic acid market is forecast to grow at a significant rate because petroleum-based succinic acid is limited by the volatility of its price and carbon footprints. The microalgal biomass of Scenedesmus acutus was acid pretreated, and the algal liquor of the resulting slurry was used in continuous fermentation for $756 \mathrm{~h}$ with Actinobacillus succinogenes $130 \mathrm{Z}$ to produce succinic acid. The maximum production and productivity of succinate were $30.5 \mathrm{~g} \mathrm{~L}^{-1}$ and $1.1 \mathrm{~g} \mathrm{~L}^{-1} \mathrm{~h}^{-1}$, respectively [165]. 


\subsection{Feed Additives}

Compared with general food, microalgae contain high amounts of protein and complete compositions of amino acids [166]. In addition, the nutritional value of microalgae is high because they contain biologically active compounds, such as pigments, lipids, vitamins, and trace elements [167]. Therefore, dry microalgal powder is good for the development of human nutrition supplements and animal feed, such as livestock, poultry, and aquatic feed additives [62]. Notably, specific microalgal strains contain high concentrations of eicosapentaenoic acid (EPA), docosahexaenoic acid (DHA), lutein, astaxanthin, carotene, and other components, which are mainly used in companies worldwide to develop cosmetic and nutrient supplements. Currently, consumer interest in algae has increased significantly. Therefore, many companies have attempted to develop foods containing microalgae and their byproducts [168]. Some microalgae species or strains, such as Chlorella, which have great conceivable uses in the human diet $[168,169]$, are already commercially used in foods [170]. However, the topic of this review is focused on the cultured microalgal biomass used as animal feed additives.

\subsubsection{Aquatic Living Organisms}

Microalgae are widely used in aquatic living organisms. Microalgae can be used as a food source for brine shrimp, copepods, and rotifers. In addition to serving as fish bait, microalgae can also be used as bait for shrimp shellfish. Microalgae contain omega-3 polyunsaturated fatty acids (EPA and DHA), which are good for the growth of fry and an increase in the survival rate of juvenile fish [171]. The vitamin C of microalgae can accumulate in fish through the food chain, and nerve conduction function in fish is improved [172]. Furthermore, microalgal pigments are often used for the color enhancement of aquatic products [167]. After feeding microalgae containing carotenoids (such as lutein, astaxanthin and/or $\beta$-carotene), the color of the fish's flesh can be enhanced, and the economic value of aquatic products can be further improved [173].

\subsubsection{Animal Feed Additives}

Technavio's report indicated that the global animal feed market size will grow more than USD 110 billion during 2021 and 2025, at a CAGR of nearly $4 \%$ and that $39 \%$ of market growth will originate from the Asia Pacific Accreditation Cooperation (APAC) during the forecast period. Microalgae-based animal feed is expected to become a major trend in the animal feed industry in the next decade [174]. Microalgae are rich in amino acids and can be the lysine source for feed additives. Lysine is the most important amino acid additive in animal feed, especially for pigs in the livestock industry. The addition of lysine in feed can help increase the daily weight gain of pigs and the lean meat percentage of pork [175]. Therefore, the microalgae containing abundant protein is suitable for feed additives application. The protein extraction was increased by freeze-drying and milling the dry microalgal biomass along with alkaline extraction [176]. Furthermore, with the addition of microalgae in feed, the specific pigments of microalgae can render the healthy color of muscle tissue of livestock and poultry in line with the preferences of consumers [177]. Polysaccharides in microalgae, such as glucan ( $\beta$-1,3-glucan), can enhance immunity, reduce animal pathogenesis and increase animal survival [178]. EPA, DHA, and antioxidants in microalgae can reduce the total cholesterol of animals and the oxidation rate of meat during storage [179]. Feed containing microalgae could increase the amount of boar sperm, the secretion of sow's milk and the survival rate of piglets [180]. A DHA-rich microalga as a dietary supplement would increase the carcass traits and meat fatty acid profile in growing-finishing pigs [181]. Microalgal feed additives were also applied to laying hens due to an increase in egg production and egg weight [182]. Astaxanthin-rich microalgae were used for the feed of laying hens; it is expected not only to increase the color of the yolks but also to produce functional eggs rich in astaxanthin, which will have great economic benefits in the egg industry. The supplementation of laying hen diets with microalgae on fatty acid content could enhance the health lipid indices and oxidative stability of hens [183]. 
However, the application of microalgae to feed is likely to face the problem of insufficient supply. If this problem of insufficient supply can be overcome, unlimited opportunities for feed by microalgae can be expected.

\subsection{Carotenoids of High-Value Products}

The global carotenoid market was estimated to be valued at USD 1127.5 million in 2019 by a report from Markets and Markets, and was projected to reach USD 1168.7 million by 2026. Carotenoids are considered powerful antioxidants and vitamin A sources and are widely applied in food, feed, nutrient supplements, skincare products, and pharmaceutical products. The limited supply of animal- or plant-derived carotenoids has increased the development of carotenoids that are produced by microbial fermentation and that are chemically synthesized. Additionally, the use of microorganisms, such as microalgae, yeast, filamentous fungi, and bacteria to produce carotenoids, is the most promising alternative because agricultural waste can be used as a source of nutrients for microbial cultivation or fermentation to further reduce production costs. At present, the main commercial pigments of carotenoids are lutein, astaxanthin, carotene, canthaxanthin, lycopene, and zeaxanthin [184]. The main reason is that microalgae are a natural resource of carotenoids that are inexpensive and that they have a high growth rate compared with plants [17]. The growth rate is 5- to 10-fold faster than that of land-based plants and they can be harvested throughout the year without seasonal harvest problems [185]. A novel twostage heterotrophic-mixotrophic (TSHM) cultivation strategy was applied to increase lutein production in the Chlorella strain. Maximum lutein production $\left(6.17 \mathrm{mg} \mathrm{g}^{-1}\right)$ and production ( $33.64 \mathrm{mg} \mathrm{L}^{-1}$ ) were obtained with the TSHM strategy, which is considered the best production model for microalgal lutein [186]. Xie et al. [187] performed a pilot-scale cultivation of Chlorella sorokiniana FZU60 with a mixotrophy/photoautotrophy two-stage strategy to produce microalgal lutein. The lutein content, production, and productivity reached $9.51 \mathrm{mg} \mathrm{g}^{-1}, 33.55 \mathrm{mg} \mathrm{L}^{-1}$, and $4.67 \mathrm{mg} \mathrm{L}^{-1} \mathrm{~d}^{-1}$, respectively, which were greater than those reported in other pilot studies. Therefore, most studies have investigated an increase in carotenoids, including lutein, production by the fast-growing microalgal Chlorella (Table 5). In Table 5, one can see that China is also actively developing research on microalgae carotenoids, to produce high-value products, to achieve economic sustainability. The focus of research is on astaxanthin and lutein of carotenoids produced from microalgae, which are the same as the current market trends for commercial applications [188].

Table 5. Carotenoids production from microalgal Chlorella.

\begin{tabular}{|c|c|c|c|c|c|c|}
\hline Microalgae & Operating Conditions & $\begin{array}{l}\text { Biomass } \\
\text { Productivity } \\
\left(\mathrm{g} \mathrm{L}^{-1} \mathrm{~d}^{-1}\right)\end{array}$ & Carotenoids & $\begin{array}{c}\text { Carotenoid } \\
\text { Content } \\
\left(\mathrm{mg} \mathrm{g}^{-1} \mathrm{DAB}^{1}\right)\end{array}$ & Country $^{2}$ & References \\
\hline Chlorella zofingiensis & $\begin{array}{l}\text { Nitrogen deficiency with } \\
\text { diphenylamine addition }\end{array}$ & 0.363 & $\begin{array}{l}\text { Astaxanthin } \\
\text { Canthaxanthin }\end{array}$ & $\begin{array}{l}0.778 \\
0.405\end{array}$ & NL & [187] \\
\hline Chlorella saccharophila & $\begin{array}{l}\text { Optimization extraction } \\
\text { by ultrasonication }\end{array}$ & - & $\begin{array}{l}\beta \text {-carotene } \\
\text { Zeaxanthin }\end{array}$ & $\begin{array}{l}4.982 \\
11.21\end{array}$ & $\mathrm{AU}$ & [189] \\
\hline Chlorella zofingiensis & $\begin{array}{l}\text { Semi-continuous } \\
\text { operation }\end{array}$ & 1.041 & Astaxanthin & 3.213 & $\mathrm{CN}$ & [190] \\
\hline Chlorella protothecoides & Salt and light stress & 0.161 & $\begin{array}{c}\text { Astaxanthin } \\
\beta \text {-carotene } \\
\text { Lutein/Zeaxanthin }\end{array}$ & $\begin{array}{l}0.131 \\
0.094 \\
1.236\end{array}$ & $\mathrm{BR}$ & [191] \\
\hline Chlorella zofingiensis & $\begin{array}{l}\text { High light irradiation and } \\
\text { nitrogen deficiency with } \\
\text { glucose-feeding }\end{array}$ & 7.031 & Astaxanthin & 0.745 & $\mathrm{CN}$ & [192] \\
\hline $\begin{array}{l}\text { Chlorella zofingiensis } \\
\text { CZ-bkt1 }\end{array}$ & $\begin{array}{l}\text { High light irradiation and } \\
\text { nitrogen deficiency }\end{array}$ & 0.301 & $\begin{array}{l}\beta \text {-carotene } \\
\text { Lutein } \\
\text { Zeaxanthin }\end{array}$ & $\begin{array}{l}5.022 \\
13.81 \\
7.013\end{array}$ & $\mathrm{CN}$ & [193] \\
\hline Chlorella zofingiensis & Nitrogen deficiency & 0.142 & Astaxanthin & 3.912 & $\mathrm{CN}$ & [194] \\
\hline $\begin{array}{l}\text { Chlorella sorokiniana } \\
\text { MB-1-M12 }\end{array}$ & $\begin{array}{c}\text { Mixotrophic } \\
\text { semi-continuous } \\
\text { operation }\end{array}$ & 3.9 & Lutein & 5.19 & TW & [33] \\
\hline
\end{tabular}


Table 5. Cont.

\begin{tabular}{|c|c|c|c|c|c|c|}
\hline Microalgae & Operating Conditions & $\begin{array}{c}\text { Biomass } \\
\text { Productivity } \\
\left(\mathrm{g} \mathrm{L}^{-1} \mathrm{~d}^{-1}\right)\end{array}$ & Carotenoids & $\begin{array}{c}\text { Carotenoid } \\
\text { Content } \\
\left(\mathrm{mg} \mathrm{g}^{-1} \mathrm{DAB}^{1}\right)\end{array}$ & Country $^{2}$ & References \\
\hline $\begin{array}{l}\text { Chlorella sorokiniana } \\
\text { MB-1-M12 }\end{array}$ & $\begin{array}{l}\text { Two-stage alternative } \\
\text { cultivation strategies }\end{array}$ & $1.42-3.54$ & Lutein & 6.17 & TW & [195] \\
\hline $\begin{array}{c}\text { Chlorella sorokiniana } \\
\text { FZU60 }\end{array}$ & $\begin{array}{l}\text { Mixotrophy/photoautotrophy } \\
\text { two-stage strategy }\end{array}$ & 33.55 & Lutein & 9.51 & $\mathrm{CN}$ & [186] \\
\hline
\end{tabular}

${ }^{1}$ DAB indicates dry algal biomass. ${ }^{2}$ Country abbreviation: Netherlands (NL), Australia (AU), China (CN), Brazil (BR), Taiwan (TW).

-: Data not shown.

\section{Refining Analyses to Reduce the Costs of Microalgae $\mathrm{CO}_{2}$ Capture and Utilization}

Microalgal production and biorefinery is a sustainable process by integrating with wastewater and flue gas to achieve $\mathrm{CO}_{2}$ reduction, carbon recycling, and wastewater treatment. For evaluating the potential of microalgae $\mathrm{CO}_{2}$ capture and utilization (CCU) strategies, robust analyses are needed to answer whether the microalgae culture system and microalgae-based biofuels production (i.e., biorefinery processes) can be constructed and/or scale-up. Besides the economic issues, the analyses are addressed, regarding the benefits on environmental health and sustainability. Reasonable assumptions for various analyses, mostly including techno-economic assessments (TEAs) and life-cycle assessments (LCAs), identified existing data, refinery processes, and information gaps must be filled to answer the questions on economics, environmental health, and/or sustainability.

\subsection{Techno-Economic Assessments (TEAs)}

TEAs calculate the capital (or investment) and operating costs of a system to arrive at the total system costs and the price of the final products. The majority of TEAs have assumed the use of a microalgae system of an open pond or closed PBR production [196]. Standardization of these models helps to assess performance against the state of technology and determine natural scalability price breakpoints. To standardize these analyses, agreement on boundary conditions is needed, including return on investment, land values, financing costs, biomass cost limitations, and resource cost curves. TEAs first require detail information on microalgae production. The information majorly includes (1) cultivation yield and microalgal composition (e.g., microalgae growth and productivity, oil content for biodiesel production, and carbohydrate content for fermented ethanol production); (2) engineering detail on $\mathrm{CO}_{2}$ capture efficiencies; (3) data on microalgae harvesting and dewatering technologies; and (4) water, as well as nutrient recycling [197].

Microalgae biofuel production has been extensively evaluated through TEAs. Chen et al. [19] reviewed many papers published between 2010 and 2013, reporting on the costs of biodiesel production from microalgae, ranging from USD 2.52-85.36 $\mathrm{gal}^{-1}$. This difference can be explained by various factors, including microalgal strains, culture system and scale, economic environment, and consideration of carbon credits. For instance, high-value byproducts could produce better financial evaluation results, and carbon credits or tax credits could lead to higher revenue. The PBR system for microalgae culture requires a large investment in the construction. Therefore, it was revealed that unit biodiesel costs of PBRs were 2-10-fold of that of open ponds with the same biodiesel production capacity [19]. Recently, the research showed a decreased average cost of microalgae-based biofuel by TEAs. Wu et al. [198] indicate that the break-even prices of diesel and ethanol are estimated about USD $0.49 \mathrm{~kg}^{-1}$ and USD $2.61 \mathrm{~kg}^{-1}$, respectively, the internal rate of return (IRR) is close to $29.21 \%$. The cost of microalgae biodiesel production in China was estimated at USD $2.29 \mathrm{~kg}^{-1}$, but it is still higher than that of commercial diesel [199]. Increasing the capacity of microalgal productivity and lipid content could efficiently reduce the cost of microalgal diesel production $[200,201]$. By a design process of wastewater-based microalgal biofuel production through hydrothermal liquefaction and hydroprocessing, the cost of biofuels could be USD 4.3 gasoline gallon equivalent ${ }^{-1}$ [202]. From the result of TEAs, an economically viable microalgal Chlorella vulgaris based biorefinery for paper industrial 
effluent treatment and bioenergy production in the scenario of 3\% photosynthetic efficiency, $75 \%$ lipids extraction efficiency, and $45 \%$ anaerobic digestion efficiency, a EUR 15.4 million net present value (NPV) and 12\% IRR were obtained [203].

\subsection{Life-Cycle Assessments (LCAs)}

LCAs are carried out based on system model and energy balances, and should include evaluations of water consumption, nutrient use, as well as environmental impacts. Comprehensive LCA boundaries should include the GHGs produced by the energy demands for $\mathrm{CO}_{2}$ capture as well as transport, biorefinery process, and microalgae cultivation. In fact, LCAs and TEAs have always emerged as critical tools for assessing the impact and feasibility of the systems of microalgae-based biofuel production [204]. The boundary for LCAs of microalgae CCU systems should include the production of $\mathrm{CO}_{2}$ through to the end products and should account for "recycle" systems. Additionally, water, fertilizer consumption, and land-use of biomass product should be calculated within LCAs to refine environmental impacts of microalgae-based biofuel production.

In effort to understand and explore opportunities to harmonize the variability, several studies have reviewed the methodologies and results of the published LCA studies on microalgae biofuels [204,205]. Collectively, these previous reviews of LCAs of algae-derived fuels have shown that the significant result variations are due to the inconsistency in (1) scope definition (e.g., system boundary and functional unit); (2) assumptions (e.g., using constant values versus random values from empirical distributions); (3) technological choices (e.g., different process trains); and (4) data sources. In the past, harmonization efforts were exerted on reducing the inconsistency on the scope definition [206]. For example, Menten et al. [205] applied meta-regression analysis to 47 LCA studies (from 2002 to 2011) and showed that the GHG emissions associated with producing 3G biofuels varied by region, with ranges of 41.6 to $136.2 \mathrm{~g} \mathrm{CO}_{2}$-eq MJ ${ }^{-1}$ (mean $=88.9 \mathrm{~g} \mathrm{CO}_{2}$-eq MJ ${ }^{-1}$ ). Quinn and Davids [204] conducted a resource assessment collected from 25 LCA studies (from 1982 to 2014) for the scalability of microalgae biofuels and found a range of -75 to $534 \mathrm{~g} \mathrm{CO}_{2}$-eq MJ ${ }^{-1}$ for biofuel production. Could researchers use data of LCAs to design an optimizing process for algal biofuel production with lower GHG emissions? Recently, a new microalgae-to-biofuels chains for producing diesel and ethanol was simultaneously reported by LCAs, the life-cycle GHG emissions for producing diesel and ethanol are $39 \mathrm{~g}$ $\mathrm{CO}_{2}$-eq $\mathrm{MJ}^{-1}$ fatty acid methyl esters and $112 \mathrm{~g} \mathrm{CO}_{2}$-eq $\mathrm{MJ}^{-1}$ ethanol, respectively [198]. It is verified that the process integration of the heat recovery scheme, the entrainer recovery tower, and $\mathrm{CO}_{2}$ recycling can effectively reduce life cycle GHG emissions of this assay. LCAs have been also used to evaluate using microalgal oil and carbohydrate as feedstock to produce biofuel, butanol. The results revealed that the annual ReCiPe endpoint score of producing $1 \mathrm{~kg}$ biobutanol is lower than that of $1 \mathrm{~kg}$ biodiesel by $54.4 \%$. It is indicated that microalgae-to-butanol chain is more ecofriendly than the microalgae-to-diesel chain due to lower LCA impacts [207]. Life cycle assessment of bioreactor for biodiesel production from microalgae revealed a fossil energy requirement variation between 3.6 and $5.7 \mathrm{MJ} \mathrm{kg}^{-1}$, a GHG emission of $0.85-1.46 \mathrm{~kg} \mathrm{CO}_{2}$-eq kg ${ }^{-1}$ biodiesel, and a reduction in fossil energy requirement of approximately $87.3 \%$ in the pilot substrate-based microalgal bioreactor [208]. The net $\mathrm{CO}_{2}$ balance was $-26 \mathrm{t} \mathrm{d}^{-1}$ in the scenario with highest photosynthetic efficiency and higher biomass productivity. That means that there is more consumption of $\mathrm{CO}_{2}$ by microalgae than that released in the biorefinery processes [203].

\section{Current Carbon Fixation and Microalga-Based Biorefinery Research}

The U.S. Department of Energy (DOE) established the Office of Energy Efficiency and Renewable Energy (EERE), which supports Research and Development (R\&D) on alternative fuels in 1993. Within EERE, the Bioenergy Technologies Office (BETO) initiated a multi-year program plan (MYPP, 2016-2020) describing many specific challenges to overcome and goals to complete in order to increase the percentage of fuel in the U.S. coming from biological sources. One of the key components of the MYPP portfolio is "R\&D on productive and 
competitive advanced algal systems". BETO organized an Algae program dedicated to researching and improving the viability of microalgae as an energy source and byproducts. The aim of MYPP on algal R\&D is to demonstrate at non-integrated process development unit-scale algae yield of 3700 gallons or equivalent biofuel intermediate per acre per year by 2020. For a longer-term goal- to demonstrate an unit-scale algal productivity of greater than 5000 gallons biofuel per acre per year by 2025 , and to validate production of 5 billion gallons per year of reliable and sustainable algae-based biofuels at the cost of $\$ 3.00$ gasoline gallon equivalent (GGE) ${ }^{-1}$ by 2030. In 2021, DOE announces USD 8 million for projects to develop algae-based co2 utilization technology that convert $\mathrm{CO}_{2}$ must show a net decrease in $\mathrm{CO}_{2}$ emissions through life cycle analysis, display a potential to generate a marketable product and show that the product displays beneficial aspects when compared to commercially available products produced with existing state-of-the-art technology.

Carbon fixation and microalga-based biorefinery research have also rapidly developed in Europe, and the European Union (EU) has supported many projects addressed on microalgal biofuels and its high value byproducts [209]. Future European League 4 Microalgal Energy (FUEL4ME) was a four-year project funded by the EU, which aimed to develop a sustainable, scalable process for biofuels and byproducts from microalgae. The 4-year, EUR 15 million SCALE program, led by Microphyt, brings together 11 top-tier international partners on a mission to develop the world's largest microalgae biorefinery. The flagship grant of SCALE is from the Bio-based Industries Joint Undertaking (BBIJU), a partnership of the European Commission and the Bio-based Industries Consortium. SCALE will further accelerate these environmental benefits by integrating renewable energy production, enhancing recycling capabilities, aiding the attainment of European climate targets, i.e., of cutting GHG emissions by $20 \%$. Moreover, the production capacity will first fully integrated increase five-fold, allowing for the development and production of more than 15 new ingredients derived from microalgae for the fields of nutrition and cosmetics. The annual capacity of SCALE will be more than 100 tons of high-value ingredients.

\section{Limitations and Needs of $\mathrm{CO}_{2}$ Fixation by Microalgal Cultivation}

Overall, 3G microalgae-based biofuel is seen as a promising energy source. Despite the many advantages of developing renewable energy and high-value byproducts, it is still difficult to form an optimizing and profitable industry for microalgal carbon fixation and refineries. The greatest limitation of microalgae biofuel production is that it is still far too expensive for commercial viability. In addition to cost limitations, current restrictions in large-scale outdoor microalgal cultivation include (1) a high-efficiency microalgae culture system with a high cost of manufacturing, especially outdoor PBR systems; (2) the illumination area and photoperiod of the microalgae culture system; (3) tolerance to changes in the external environment, such as temperature and light; (4) the possibility of contamination from microorganisms and insects in a large-scale culture system; (5) the concentration, source, composition, feed rate, and transmission method of $\mathrm{CO}_{2} ;(6)$ an effective increase in microalgal biomass production and the contents of microalgal oil/high value products; (7) more energy consumption of the refinery procession of microalgal biomass; and (8) biosafety risk and governmental policy issues if microalgal biomass produced from wastewater and flue gas aeration is used to generate animal feed and food additives. Each of the above restrictions may be (or has been) resolved in individual studies, but establishing a process of microalgal carbon fixation that can overcome all problems comprehensively is still a difficult task. For example, wastewater utilization and flue gas aeration could help to significantly reduce the cultural costs of microalgal cultivation $[42,210,211]$. The production of microalgal biofuels integrated with other valuable byproducts from microalgal biomass could be a feasible way to reduce the biofuel cost from microalgae [19,212]. However, it is easy to limit the development of high-value byproducts for microalgal biomass due to biosafety considerations [49]. In addition, following microalgal cultivation, microalgae biomass recovery and dewatering processes not only increase costs, but also may increase carbon emissions by energy consumption [213,214]. Therefore, how to bal- 
ance the conditions of $\mathrm{CO}_{2}$ fixation, renewable energy production, energy consumption, economic feasibility, and environmental health in microalgal cultivations and microalgal biomass refineries, to achieve net zero carbon emissions and economic profits, are global research goals.

Regarding cost limitations, it is necessary to establish a low-cost process for mass production from microalgae $[44,209]$. At this time, the industry is still experimenting on a variety of methods to culture microalgae, with the most popular models being open pond systems and/or closed-loop systems, i.e., PBRs [215]. Regardless, both systems are still unaccepted because of economic issues. PBRs provide the most effective systems for producing high-quality microalgae, but they are expensive in light of operations and maintenance. Therefore, PBRs are not economically accepted as a system of microalgae culture for commercial production. Moreover, more funding and research are necessary to approve the potential for microalgae biofuel in commercially viable products. Although many biorefinery technologies are moving out of the laboratory and into commercial-scale production, the production costs of microalgae-based biofuel is still high; in particular, the costs at the beginning to scale-up, need to be resolved, and novel technology is new and still developing [216,217]. Furthermore, the Conference of the Parties (COP) 26 was held in 2021, with the aim of making all countries committed to achieving net zero carbon emissions, and even more, expressing that there is no time to delay in the development of carbon reduction technologies. That is-microalgae-based biofuels are promising energy sources to be developed.

\section{Future Direction of Research}

As global warming is becoming more serious-how to effectively reduce $\mathrm{CO}_{2}$ is still an important issue. Therefore, research on the development of sustainable microalgae biological carbon fixation technology needs to continue. Future research directions should focus on the potential for long-term stable growth of microalgal strains and applicable large-scale microalgae cultivation systems under outdoor cultivation, which can use $\mathrm{CO}_{2}$ from exhaust gas or utilize the nutrients from wastewater. The potential microalgal strain will not cause damage to the surrounding environmental ecosystem. Coupled with global climate change challenges-researchers should focus on how to make the microalgal strains withstand changes in the surrounding environment during the cultivation process to continuously achieve $\mathrm{CO}_{2}$ carbon fixation. Under the premise of a low-cost harvesting process, the harvesting microalgae biomass will be fully utilized to develop biofuels, fine chemicals, and high-value products. The overall process involves "checking" the economic sustainability and environmental sustainability, to achieve a net positive energy balance and net zero carbon emissions (even to net negative carbon emissions).

\section{Conclusions}

Microalgae-based $\mathrm{CO}_{2}$ fixation technology is certainly promising. Compared with applying microalgae cultivation to $\mathrm{CO}_{2}$ fixation alone, which is unlikely to be economically attractive, there is an opportunity to reduce costs and simultaneously achieve $\mathrm{CO}_{2}$ reduction and wastewater treatment by integrating wastewater and flue gas in microalgae cultivation. The resulting microalgal biomass can also be a feedstock for biodiesel, biobutanol, biogas, aviation fuels, and biochar, lactic acid, and succinic acid of fine chemicals, feed additives, and carotenoids of high-value byproducts, to apply in cosmetics, food, and nutrient supplements. However, to balance the conditions of $\mathrm{CO}_{2}$ fixation, renewable energy production, energy consumption, economic feasibility, and environmental sustainability in microalgal cultivation and microalgal biomass refineries, to achieve net zero carbon emissions, and economic profit, are still global research goals. In summary, screening higher $\mathrm{CO}_{2}$ fixation efficiency of microalgal strains, establishing large-scale microalgal cultivation systems, and long-term stable processes for outdoor cultivation, harvesting the resulting microalgal biomass by low-cost harvesting processes, and developing biorefinery processes, evaluating the economic and environment assessment of microalgal $\mathrm{CO}_{2}$ fixation 
technology, need to be studied further. All countries should simultaneously pay attention to the environmental disasters caused by carbon emissions, and take action to improve it.

Author Contributions: Conceptualization, C.-M.K., Y.-L.S., H.-T.W. and C.-S.L.; writing-original draft preparation, C.-M.K., Y.-L.S., C.-H.L. (Cheng-Han Lin) and C.-H.L. (Chao-Hsu Lin); writingreview and editing, C.-M.K., Y.-L.S., H.-T.W. and C.-S.L.; supervision, C.-S.L. All authors have read and agreed to the published version of the manuscript.

Funding: This work received no external funding.

Institutional Review Board Statement: Not applicable.

Informed Consent Statement: All data in this study were obtained from published material in scientific journals, referenced in the paper, and can be obtained by any individual with access.

Data Availability Statement: The data presented in this study are available upon request from the corresponding author.

Acknowledgments: This work was supported by grants MOST 110-2313-B-A49-001-MY3 and MOST 107-2313-B-009-002-MY3 from the Ministry of Science and Technology (MOST), Taiwan. This work was also financially supported by the "Center for Intelligent Drug Systems and Smart Bio-devices (IDS2B)" from The Featured Areas Research Center Program within the framework of the Higher Education Sprout Project of the National Yang Ming Chiao Tung University and Ministry of Education (MOE), Taiwan.

Conflicts of Interest: The authors declare no conflict of interest.

$\begin{array}{ll}\text { Abbreviations } \\ \text { 3G } & \text { third-generation } \\ \mathrm{ABE} & \text { acetone-butanol-ethanol } \\ \mathrm{APAC} & \text { Asia Pacific Accreditation Cooperation } \\ \mathrm{AU} & \text { Australia } \\ \mathrm{BBIJU} & \text { Bio-based Industries Joint Undertaking } \\ \mathrm{BETO} & \text { Bioenergy Technologies Office } \\ \mathrm{BR} & \text { Brazil } \\ \mathrm{CAGR} & \text { compound annual growth rate } \\ \mathrm{CCU} & \text { CO } 2 \text { capture and utilization } \\ \mathrm{CH} & \text { methane } \\ \mathrm{CN} & \text { China } \\ \mathrm{CO}{ }_{2} & \text { carbon dioxide } \\ \mathrm{CO}{ }_{3}^{2-} & \text { carbonate } \\ \mathrm{COD} & \text { chemical oxygen demand } \\ \mathrm{COP} & \text { Conference of the Parties } \\ \mathrm{DHA} & \text { docosahexaenoic acid } \\ \mathrm{DIET} & \text { direct interspecies electron transfer } \\ \mathrm{DOE} & \text { Department of Energy } \\ \mathrm{EERE} & \text { Energy Efficiency and Renewable Energy } \\ \mathrm{EPA} & \text { eicosapentaenoic acid } \\ \mathrm{ES} & \text { Spain } \\ \mathrm{EU} & \text { European Union } \\ \mathrm{Fe}{ }_{3} \mathrm{O}_{4} & \text { ferroferric oxide } \\ \mathrm{FI} & \text { Finland } \\ \mathrm{FUEL} 4 \mathrm{ME} & \text { FUture European League } 4 \text { Microalgal Energy } \\ \mathrm{GB} & \text { United Kingdom } \\ \mathrm{GGE} & \text { gasoline gallon equivalent } \\ \mathrm{GHGs} & \text { greenhouse gases } \\ \mathrm{HCO}{ }_{3}^{-} & \text {bicarbonate } \\ \mathrm{HK} & \text { Hong Kong } \\ \mathrm{H}_{2} \mathrm{~S} & \text { hydrogen sulfide } \\ & \end{array}$




\begin{tabular}{|c|c|}
\hline $\mathrm{HSO}_{3}{ }^{-}$ & bisulfite \\
\hline IBA & indole-3-butyric acid \\
\hline IN & India \\
\hline IRR & internal rate of return \\
\hline IT & Italy \\
\hline KR & Korea \\
\hline LCAs & life cycle assessments \\
\hline LED & light-emitting diode \\
\hline $\mathrm{MX}$ & Mexico \\
\hline MY & Malaysia \\
\hline MYPP & Multi-Year Program Plan \\
\hline $\mathrm{N}_{2}$ & nitrogen \\
\hline $\mathrm{NaNO}_{3}$ & sodium nitrate \\
\hline $\mathrm{NH}_{3}$ & ammonia \\
\hline NL & Netherlands \\
\hline $\mathrm{NO}_{x}$ & nitrogen oxides \\
\hline NOAA & National Oceanic and Atmospheric Administration \\
\hline NPV & net present value \\
\hline NTG & $N$-methyl- $N$-nitro- $N$-nitrosoguanidine \\
\hline PBRs & photobioreactors \\
\hline PL & Poland \\
\hline POME & Palm oil mill effluent \\
\hline PsRC & PBRs/raceway circulating \\
\hline $\mathrm{R} \& \mathrm{D}$ & Research and Development \\
\hline Rubisco & Ribulose-1,5-bisphosphate carboxylase/oxygenase \\
\hline SCFAs & short-chain fatty acids \\
\hline $\mathrm{SO}_{2}$ & sulfur dioxide \\
\hline $\mathrm{SO}_{3}^{2-}$ & sulfite \\
\hline $\mathrm{SO}_{4}^{2-}$ & sulfate \\
\hline $\mathrm{SO}_{\mathrm{x}}$ & sulfur oxides \\
\hline TEAs & technical and economic assessments \\
\hline $\mathrm{TN}$ & total nitrogen \\
\hline $\mathrm{TP}$ & total phosphorus \\
\hline TSHM & two-stage heterotrophic-mixotrophic \\
\hline TW & Taiwan \\
\hline US & United States \\
\hline $\mathrm{ZA}$ & South Africa \\
\hline
\end{tabular}

\section{References}

1. Nithin, B.R.; Bhuyar, P.; Trejo, M.; Rahim, M.H.A.; Maniam, G.P.; Govindan, N. Culturing of green photosynthetic microalgae (Chlorella sp.) using palm oil mill effluent (POME) for future biodiesel production. Maejo Int. J. Energy Environ. Commun. 2020, 2, 1-8. [CrossRef]

2. Bhuyar, P.; Yusoff, M.M.; Rahim, M.H.A.; Sundararaju, S.; Maniam, G.P.; Govindan, N. Effect of plant hormones on the production of biomass and lipid extraction for biodiesel production from microalgae Chlorella sp. J. Microbiol. Biotechnol. Food Sci. 2020, 9 , 671-674. [CrossRef]

3. Bhuyar, P.; Sundararaju, S.; Rahim, M.H.A.; Ramaraj, R.; Maniam, G.P.; Govindan, N. Microalgae cultivation using palm oil mill effluent as growth medium for lipid production with the effect of $\mathrm{CO}_{2}$ supply and light intensity. Biomass Convers. Biorefinery 2021, 11, 1555-1563. [CrossRef]

4. Jayakumar, S.; Bhuyar, P.; Pugazhendhi, A.; Rahim, M.H.A.; Maniam, G.P.; Govindan, N. Effects of light intensity and nutrients on the lipid content of marine microalga (diatom) Amphiprora sp. for promising biodiesel production. Sci. Total Environ. 2021, 768, 145471. [CrossRef]

5. Schewe, J.; Heinke, J.; Gerten, D.; Haddeland, I.; Arnell, N.W.; Clark, D.B.; Dankers, R.; Eisner, S.; Fekete, B.M.; Colón-González, F.j; et al. Multimodel assessment of water scarcity under climate change. Proc. Natl. Acad. Sci. USA 2014, 111, 3245-3250. [CrossRef] [PubMed]

6. Fu, B.; Li, B.; Gasser, T.; Tao, S.; Ciais, P.; Piao, S.; Balkanski, Y.; Li, W.; Yin, T.; Han, L.; et al. The contributions of individual countries and regions to the global radiative forcing. Proc. Natl. Acad. Sci. USA 2021, 118, e2018211118. [CrossRef] [PubMed]

7. Zhao, B.; Su, Y. Process effect of microalgal-carbon dioxide fixation and biomass production: A review. Renew. Sustain. Energy Rev. 2014, 31, 121-132. [CrossRef] 
8. Veldkamp, T.I.E.; Eisner, S.; Wada, Y.; Aerts, J.C.J.H.; Ward, P.J. Sensitivity of water scarcity events to ENSO-driven climate variability at the global scale. Hydrol. Earth Syst. Sci. 2015, 19, 4081-4098. [CrossRef]

9. Zhu, B.; Shen, H.; Li, Y.; Liu, Q.; Jin, G.; Han, J.; Zhao, Y.; Pan, K. Large-Scale Cultivation of Spirulina for Biological CO 2 Mitigation in Open Raceway Ponds Using Purified $\mathrm{CO}_{2}$ From a Coal Chemical Flue Gas. Front. Bioeng. Biotechnol. 2020, 7, 441. [CrossRef] [PubMed]

10. Jäger-Waldau, A.; Kougias, I.; Taylor, N.; Thiel, C. How photovoltaics can contribute to GHG emission reductions of $55 \%$ in the EU by 2030. Renew. Sustain. Energy Rev. 2020, 126, 109836. [CrossRef]

11. Keyßer, L.T.; Lenzen, M. $1.5^{\circ} \mathrm{C}$ degrowth scenarios suggest the need for new mitigation pathways. Nat. Commun. 2021, $12,2676$. [CrossRef] [PubMed]

12. Boyd, P.W.; Claustre, H.; Levy, M.; Siegel, D.A.; Weber, T. Multi-faceted particle pumps drive carbon sequestration in the ocean. Nat. Cell Biol. 2019, 568, 327-335. [CrossRef] [PubMed]

13. Lu, X.; Vitousek, P.M.; Mao, Q.; Gilliam, F.S.; Luo, Y.; Turner, B.L.; Zhou, G.; Mo, J. Nitrogen deposition accelerates soil carbon sequestration in tropical forests. Proc. Natl. Acad. Sci. USA 2021, 118, e2020790118. [CrossRef] [PubMed]

14. Adamczyk, B.; Heinonsalo, J.; Simon, J. Mechanisms of Carbon Sequestration in Highly Organic Ecosystems-Importance of Chemical Ecology. ChemistryOpen 2020, 9, 464. [CrossRef]

15. Li, J.; Tang, X.; Pan, K.; Zhu, B.; Li, Y.; Ma, X.; Zhao, Y. The regulating mechanisms of $\mathrm{CO}_{2}$ fixation and carbon allocations of two Chlorella sp. strains in response to high $\mathrm{CO}_{2}$ levels. Chemosphere 2020, 247, 125814. [CrossRef] [PubMed]

16. Jaiswal, K.K.; Dutta, S.; Banerjee, I.; Pohrmen, C.B.; Kumar, V. Photosynthetic microalgae-based carbon sequestration and generation of biomass in biorefinery approach for renewable biofuels for a cleaner environment. Biomass Convers. Biorefinery 2021, 1-19. [CrossRef]

17. Zhou, W.; Wang, J.; Chen, P.; Ji, C.; Kang, Q.; Lu, B.; Li, K.; Liu, J.; Ruan, R. Bio-mitigation of carbon dioxide using microalgal systems: Advances and perspectives. Renew. Sustain. Energy Rev. 2017, 76, 1163-1175. [CrossRef]

18. Lim, Y.A.; Chong, M.N.; Foo, S.C.; Ilankoon, I. Analysis of direct and indirect quantification methods of $\mathrm{CO}_{2}$ fixation via microalgae cultivation in photobioreactors: A critical review. Renew. Sustain. Energy Rev. 2021, 137, 110579. [CrossRef]

19. Chen, J.; Li, J.; Dong, W.; Zhang, X.; Tyagi, R.D.; Drogui, P.; Surampalli, R.Y. The potential of microalgae in biodiesel production. Renew. Sustain. Energy Rev. 2018, 90, 336-346. [CrossRef]

20. Hosseini, N.S.; Shang, H.; Scott, J.A. Biosequestration of industrial off-gas $\mathrm{CO}_{2}$ for enhanced lipid productivity in open microalgae cultivation systems. Renew. Sustain. Energy Rev. 2018, 92, 458-469. [CrossRef]

21. Chisti, Y. Biodiesel from microalgae. Biotechnol. Adv. 2007, 25, 294-306. [CrossRef]

22. Chisti, Y. Biodiesel from microalgae beats bioethanol. Trends Biotechnol. 2008, 26, 126-131. [CrossRef] [PubMed]

23. Singh, S.P.; Singh, P. Effect of $\mathrm{CO}_{2}$ concentration on algal growth: A review. Renew. Sustain. Energy Rev. 2014, 38, 172-179. [CrossRef]

24. Kuo, C.-M.; Jian, J.-F.; Sun, Y.-L.; Lin, T.-H.; Yang, Y.-C.; Zhang, W.-X.; Chang, H.-F.; Lai, J.-T.; Chang, J.-S.; Lin, C.-S. An efficient Photobioreactors / Raceway circulating system combined with alkaline- $\mathrm{CO}_{2}$ capturing medium for microalgal cultivation. Bioresour. Technol. 2018, 266, 398-406. [CrossRef] [PubMed]

25. Kuo, C.-M.; Chen, T.-Y.; Lin, T.-H.; Kao, C.-Y.; Lai, J.-T.; Chang, J.-S.; Lin, C.-S. Cultivation of Chlorella sp. GD using piggery wastewater for biomass and lipid production. Bioresour. Technol. 2015, 194, 326-333. [CrossRef] [PubMed]

26. Gabrielyan, L.; Hakobyan, L.; Trchounian, A. Characterization of light-dependent hydrogen production by new green microalga Parachlorella kessleri in various conditions. J. Photochem. Photobiol. Biol. 2017, 175, 207-210. [CrossRef] [PubMed]

27. Karpagam, R.; Jawaharraj, K.; Gnanam, R. Review on integrated biofuel production from microalgal biomass through the outset of transesterification route: A cascade approach for sustainable bioenergy. Sci. Total Environ. 2021, 766, 144236. [CrossRef]

28. Bibi, R.; Ahmad, Z.; Imran, M.; Hussain, S.; Ditta, A.; Mahmood, S.; Khalid, A. Algal bioethanol production technology: A trend towards sustainable development. Renew. Sustain. Energy Rev. 2017, 71, 976-985. [CrossRef]

29. Wang, F.; Liu, T.; Guan, W.; Xu, L.; Huo, S.; Ma, A.; Zhuang, G.; Terry, N. Development of a Strategy for Enhancing the Biomass Growth and Lipid Accumulation of Chlorella sp. UJ-3 Using Magnetic $\mathrm{Fe}_{3} \mathrm{O}_{4}$ Nanoparticles. Nanomaterials 2021, 11, 2802 [CrossRef] [PubMed]

30. Araujo, G.S.; Silva, J.W.A.; Viana, C.A.S.; Fernandes, F.A.N. Effect of sodium nitrate concentration on biomass and oil production of four microalgae species. Int. J. Sustain. Energy 2019, 39, 41-50. [CrossRef]

31. Rana, R.S.; Prajapati, S.K. Stimulating effects of glycerol on the growth, phycoremediation and biofuel potential of Chlorella pyrenoidosa cultivated in wastewater. Environ. Technol. Innov. 2021, 24, 102082. [CrossRef]

32. Ramalingam, D.; Sen, R. A sustainable perspective of microalgal biorefinery for co-production and recovery of high-value carotenoid and biofuel with $\mathrm{CO}_{2}$ valorization. Biofuels Bioprod. Bioref. 2020, 14, 879-897.

33. Chen, J.-H.; Kato, Y.; Matsuda, M.; Chen, C.-Y.; Nagarajan, D.; Hasunuma, T.; Kondo, A.; Dong, C.-D.; Lee, D.-J.; Chang, J.-S. A novel process for the mixotrophic production of lutein with Chlorella sorokiniana MB-1-M12 using aquaculture wastewater. Bioresour. Technol. 2019, 290, 121786. [CrossRef]

34. Cuevas-Castillo, G.A.; Navarro-Pineda, F.S.; Rodríguez, S.A.B.; Rivero, J.C.S. Advances on the processing of microalgal biomass for energy-driven biorefineries. Renew. Sustain. Energy Rev. 2020, 125, 109606. [CrossRef]

35. Mehariya, S.; Goswami, R.K.; Karthikeysan, O.P.; Verma, P. Microalgae for high-value products: A way towards green nutraceutical and pharmaceutical compounds. Chemosphere 2021, 280, 130553. [CrossRef] [PubMed] 
36. Foo, S.C.; Khoo, K.S.; Ooi, C.W.; Show, P.L.; Khong, N.M.H.; Yusoff, F.M. Meeting Sustainable Development Goals: Alternative Extraction Processes for Fucoxanthin in Algae. Front. Bioeng. Biotechnol. 2021, 8, 1371. [CrossRef]

37. Minhas, A.K.; Hodgson, P.; Barrow, C.; Adholeya, A. A Review on the Assessment of Stress Conditions for Simultaneous Production of Microalgal Lipids and Carotenoids. Front. Microbiol. 2016, 7, 546. [CrossRef]

38. Yousuf, A. Microalgae Cultivation for Biofuels Production, 1st ed.; Academic Press: London, UK, 2020; pp. 1-9.

39. Jacob-Lopes, E.; Maroneze, M.M.; Queiroz, M.I.; Zepka, L.Q. Handbook of Microalgae-Based Processes and Products, 1st ed.; Academic Press: London, UK, 2020; pp. 127-163.

40. Bhola, V.; Swalaha, F.M.; Nasr, M.; Bux, F. Fuzzy intelligence for investigating the correlation between growth performance and metabolic yields of a Chlorella sp. exposed to various flue gas schemes. Bioresour. Technol. 2017, 243, 1078-1086. [CrossRef] [PubMed]

41. Chen, H.; Wang, J.; Zheng, Y.; Zhan, J.; He, C.; Wang, Q. Algal biofuel production coupled bioremediation of biomass power plant wastes based on Chlorella sp. C2 cultivation. Appl. Energy 2018, 211, 296-305. [CrossRef]

42. Molazadeh, M.; Ahmadzadeh, H.; Pourianfar, H.R.; Lyon, S.; Rampelotto, P.H. The Use of Microalgae for Coupling Wastewater Treatment With $\mathrm{CO}_{2}$ Biofixation. Front. Bioeng. Biotechnol. 2019, 7, 42. [CrossRef]

43. Shahid, A.; Malik, S.; Zhu, H.; Xu, J.; Nawaz, M.Z.; Nawaz, S.; Alam, A.; Mehmood, M.A. Cultivating microalgae in wastewater for biomass production, pollutant removal, and atmospheric carbon mitigation; a review. Sci. Total Environ. 2020, 704, 135303. [CrossRef]

44. Chiu, S.-Y.; Kao, C.-Y.; Chen, T.-Y.; Chang, Y.-B.; Kuo, C.-M.; Lin, C.-S. Cultivation of microalgal Chlorella for biomass and lipid production using wastewater as nutrient resource. Bioresour. Technol. 2015, 184, 179-189. [CrossRef]

45. Wei, L.; Shen, C.; El Hajjami, M.; You, W.; Wang, Q.; Zhang, P.; Ji, Y.; Hu, H.; Hu, Q.; Poetsch, A.; et al. Knockdown of carbonate anhydrase elevates Nannochloropsis productivity at high $\mathrm{CO}_{2}$ level. Metab. Eng. 2019, 54, 96-108. [CrossRef]

46. Solovchenko, A.; Khozin-Goldberg, I. High- $\mathrm{CO}_{2}$ tolerance in microalgae: Possible mechanisms and implications for biotechnology and bioremediation. Biotechnol. Lett. 2013, 35, 1745-1752. [CrossRef]

47. Ong, S.-C.; Kao, C.-Y.; Chiu, S.-Y.; Tsai, M.-T.; Lin, C.-S. Characterization of the thermal-tolerant mutants of Chlorella sp. with high growth rate and application in outdoor photobioreactor cultivation. Bioresour. Technol. 2010, 101, 2880-2883. [CrossRef]

48. Kao, C.-Y.; Chen, T.-Y.; Chang, Y.-B.; Chiu, T.-W.; Lin, H.-Y.; Chen, C.-D.; Chang, J.-S.; Lin, C.-S. Utilization of carbon dioxide in industrial flue gases for the cultivation of microalga Chlorella sp. Bioresour. Technol. 2014, 166, 485-493. [CrossRef]

49. Kuo, C.-M.; Jian, J.-F.; Lin, T.-H.; Chang, Y.-B.; Wan, X.-H.; Lai, J.-T.; Chang, J.-S.; Lin, C.-S. Simultaneous microalgal biomass production and $\mathrm{CO}_{2}$ fixation by cultivating Chlorella sp. GD with aquaculture wastewater and boiler flue gas. Bioresour. Technol. 2016, 221, 241-250. [CrossRef] [PubMed]

50. Kuo, C.-M.; Lin, T.-H.; Yang, Y.-C.; Zhang, W.-X.; Lai, J.-T.; Wu, H.-T.; Chang, J.-S.; Lin, C.-S. Ability of an alkali-tolerant mutant strain of the microalga Chlorella sp. AT1 to capture carbon dioxide for increasing carbon dioxide utilization efficiency. Bioresour. Technol. 2017, 244, 243-251. [CrossRef] [PubMed]

51. Vadlamani, A.; Viamajala, S.; Pendyala, B.; Varanasi, S. Cultivation of Microalgae at Extreme Alkaline pH Conditions: A Novel Approach for Biofuel Production. ACS Sustain. Chem. Eng. 2017, 5, 7284-7294. [CrossRef]

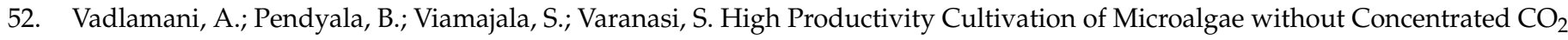
Input. ACS Sustain. Chem. Eng. 2019, 7, 1933-1943. [CrossRef]

53. Santos, A.; Lamers, P.; Janssen, M.; Wijffels, R. Biomass and lipid productivity of Neochloris oleoabundans under alkaline-saline conditions. Algal Res. 2013, 2, 204-211. [CrossRef]

54. Sachdeva, N.; Gupta, R.P.; Mathur, A.S.; Tuli, D.K. Enhanced lipid production in thermo-tolerant mutants of Chlorella pyrenoidosa NCIM 2738. Bioresour. Technol. 2016, 221, 576-587. [CrossRef]

55. Lee, T.-M.; Tseng, Y.-F.; Cheng, C.-L.; Chen, Y.-C.; Lin, C.-S.; Su, H.-Y.; Chow, T.-J.; Chen, C.-Y.; Chang, J.-S. Characterization of a heat-tolerant Chlorella sp. GD mutant with enhanced photosynthetic $\mathrm{CO}_{2}$ fixation efficiency and its implication as lactic acid fermentation feedstock. Biotechnol. Biofuels 2017, 10, 214. [CrossRef] [PubMed]

56. Varshney, P.; Beardall, J.; Bhattacharya, S.; Wangikar, P.P. Isolation and biochemical characterisation of two thermophilic green algal species- Asterarcys quadricellulare and Chlorella sorokiniana, which are tolerant to high levels of carbon dioxide and nitric oxide. Algal Res. 2018, 30, 28-37. [CrossRef]

57. Mehta, P.; Rani, R.; Gupta, R.; Mathur, A.S.; Puri, S.K. Biomass and lipid production of a novel freshwater thermo-tolerant mutant strain of Chlorella pyrenoidosa NCIM 2738 in seawater salinity recycled medium. Algal Res. 2018, 36, 88-95. [CrossRef]

58. Chou, H.-H.; Su, H.-Y.; Song, X.-D.; Chow, T.-J.; Chen, C.-Y.; Chang, J.-S.; Lee, T.-M. Isolation and characterization of Chlorella sp. mutants with enhanced thermo- and $\mathrm{CO}_{2}$ tolerances for $\mathrm{CO}_{2}$ sequestration and utilization of flue gases. Biotechnol. Biofuels 2019, 12, 251. [CrossRef] [PubMed]

59. Li, D.; Wang, L.; Zhao, Q.; Wei, W.; Sun, Y. Improving high carbon dioxide tolerance and carbon dioxide fixation capability of Chlorella sp. by adaptive laboratory evolution. Bioresour. Technol. 2015, 185, 269-275. [CrossRef]

60. Jain, D.; Ghonse, S.S.; Trivedi, T.; Fernandes, G.L.; Menezes, L.D.; Damare, S.R.; Mamatha, S.; Kumar, S.; Gupta, V. CO 2 fixation and production of biodiesel by Chlorella vulgaris NIOCCV under mixotrophic cultivation. Bioresour. Technol. 2019, 273, 672-676. [CrossRef] [PubMed]

61. Kao, C.-Y.; Chiu, S.-Y.; Huang, T.-T.; Dai, L.; Hsu, L.-K.; Lin, C.-S. Ability of a mutant strain of the microalga Chlorella sp. to capture carbon dioxide for biogas upgrading. Appl. Energy 2012, 93, 176-183. [CrossRef] 
62. Kuo, C.M.; Chang, Y.B.; Lin, T.H.; Yang, Y.C.; Zhang, W.X.; Lai, J.T.; Wu, H.T.; Lin, C.S. Effects of a protein-enriched crude lysate from Chlorella sp. against acetaminophen-induced liver injury. IOSR-JBB 2017, 3, 82-88. [CrossRef]

63. Chiu, S.-Y.; Kao, C.-Y.; Huang, T.-T.; Lin, C.-J.; Ong, S.-C.; Chen, C.-D.; Chang, J.-S.; Lin, C.-S. Microalgal biomass production and on-site bioremediation of carbon dioxide, nitrogen oxide and sulfur dioxide from flue gas using Chlorella sp. cultures. Bioresour. Technol. 2011, 102, 9135-9142. [CrossRef] [PubMed]

64. Cheng, D.; Li, X.; Yuan, Y.; Zhao, Q. Kinetic model for effects of simulated flue gas onto growth profiles of Chlorella sp. AE10 and Chlorella sp. Cv. Biotechnol. Appl. Biochem. 2020, 67, 783-789. [CrossRef] [PubMed]

65. Kumar, K.; Banerjee, D.; Das, D. Carbon dioxide sequestration from industrial flue gas by Chlorella sorokiniana. Bioresour. Technol. 2014, 152, 225-233. [CrossRef]

66. Praveenkumar, R.; Kim, B.; Choi, E.; Lee, K.; Park, J.-Y.; Lee, J.-S.; Lee, Y.-C.; Oh, Y.-K. Improved biomass and lipid production in a mixotrophic culture of Chlorella sp. KR-1 with addition of coal-fired flue-gas. Bioresour. Technol. 2014, 171, 500-505. [CrossRef] [PubMed]

67. Duarte, J.H.; Fanka, L.S.; Costa, J.A.V. Utilization of simulated flue gas containing $\mathrm{CO}_{2}, \mathrm{SO}_{2}, \mathrm{NO}$ and ash for Chlorella fusca cultivation. Bioresour. Technol. 2016, 214, 159-165. [CrossRef]

68. García-Cubero, R.; Moreno-Fernández, J.; García-González, M. Potential of Chlorella vulgaris to Abate Flue Gas. Waste BiomassValorization 2017, 9, 2015-2019. [CrossRef]

69. Hanifzade, M.M.; Nabati, Z.; Tavakoli, O.; Sarrafzadeh, M.H. Waste to Energy from Flue Gas of Industrial Plants to Biodiesel: Effect of $\mathrm{CO}_{2}$ on Microalgae Growth. Int. J. Waste Resour. 2017, 7, 2. [CrossRef]

70. Yadav, G.; Karemore, A.; Dash, S.K.; Sen, R. Performance evaluation of a green process for microalgal $\mathrm{CO}_{2}$ sequestration in closed photobioreactor using flue gas generated in-situ. Bioresour. Technol. 2015, 191, 399-406. [CrossRef] [PubMed]

71. Kandimalla, P.; Desi, S.; Vurimindi, H. Mixotrophic cultivation of microalgae using industrial flue gases for biodiesel production. Environ. Sci. Pollut. Res. 2015, 23, 9345-9354. [CrossRef]

72. Cheng, D.; Li, X.; Yuan, Y.; Yang, C.; Tang, T.; Zhao, Q.; Sun, Y. Adaptive evolution and carbon dioxide fixation of Chlorella sp. in simulated flue gas. Sci. Total Environ. 2019, 650, 2931-2938. [CrossRef] [PubMed]

73. Moreno-Garcia, L.; Gariépy, Y.; Bourdeau, N.; Barnabé, S.; Raghavan, G. Optimization of the proportions of four wastewaters in a blend for the cultivation of microalgae using a mixture design. Bioresour. Technol. 2019, 283, 168-173. [CrossRef] [PubMed]

74. Hussain, F.; Shah, S.Z.; Ahmad, H.; Abubshait, S.A.; Abubshait, H.A.; Laref, A.; Manikandan, A.; Kusuma, H.S.; Iqbal, M. Microalgae an ecofriendly and sustainable wastewater treatment option: Biomass application in biofuel and bio-fertilizer production. A review. Renew. Sustain. Energy Rev. 2021, 137, 110603. [CrossRef]

75. Salama, E.-S.; Kurade, M.; Abou-Shanab, R.A.; El-Dalatony, M.M.; Yang, I.-S.; Min, B.; Jeon, B.-H. Recent progress in microalgal biomass production coupled with wastewater treatment for biofuel generation. Renew. Sustain. Energy Rev. 2017, 79, 1189-1211. [CrossRef]

76. Lu, W.; Wang, Z.; Wang, X.; Yuan, Z. Cultivation of Chlorella sp. using raw dairy wastewater for nutrient removal and biodiesel production: Characteristics comparison of indoor bench-scale and outdoor pilot-scale cultures. Bioresour. Technol. 2015, 192, 382-388. [CrossRef] [PubMed]

77. Marjakangas, J.M.; Chen, C.-Y.; Lakaniemi, A.-M.; Puhakka, J.A.; Whang, L.-M.; Chang, J.-S. Selecting an indigenous microalgal strain for lipid production in anaerobically treated piggery wastewater. Bioresour. Technol. 2015, 191, 369-376. [CrossRef]

78. Nam, K.; Lee, H.; Heo, S.-W.; Chang, Y.K.; Han, J.-I. Cultivation of Chlorella vulgaris with swine wastewater and potential for algal biodiesel production. Environ. Boil. Fishes 2017, 29, 1171-1178. [CrossRef]

79. Zhu, L.-D.; Li, Z.-H.; Guo, D.-B.; Huang, F.; Nugroho, Y.; Xia, K. Cultivation of Chlorella sp. with livestock waste compost for lipid production. Bioresour. Technol. 2017, 223, 296-300. [CrossRef]

80. Cheng, D.; Ngo, H.; Guo, W.; Chang, S.; Nguyen, D.D.; Kumar, S. Microalgae biomass from swine wastewater and its conversion to bioenergy. Bioresour. Technol. 2019, 275, 109-122. [CrossRef]

81. Toze, S. Reuse of effluent water-benefits and risks. Agric. Water Manag. 2006, 80, 147-159. [CrossRef]

82. Abdel-Raouf, N.; Al-Homaidan, A.A.; Ibraheem, I.B.M. Microalgae and wastewater treatment. Saudi J. Biol. Sci. 2012, 19, 257-275. [CrossRef]

83. Chen, C.-Y.; Kuo, E.-W.; Nagarajan, D.; Dong, C.-D.; Lee, D.-J.; Varjani, S.; Lam, S.S.; Chang, J.-S. Semi-batch cultivation of Chlorella sorokiniana AK-1 with dual carriers for the effective treatment of full strength piggery wastewater treatment. Bioresour. Technol. 2021, 326, 124773. [CrossRef]

84. Tao, R.; Kinnunen, V.; Praveenkumar, R.; Lakaniemi, A.-M.; Rintala, J. Comparison of Scenedesmus acuminatus and Chlorella vulgaris cultivation in liquid digestates from anaerobic digestion of pulp and paper industry and municipal wastewater treatment sludge. Environ. Boil. Fishes 2017, 29, 2845-2856. [CrossRef]

85. Mohseni, A.; Kube, M.; Fan, L.; Roddick, F.A. Potential of Chlorella vulgaris and Nannochloropsis salina for nutrient and organic matter removal from municipal wastewater reverse osmosis concentrate. Environ. Sci. Pollut. Res. 2020, 27, 26905-26914. [CrossRef]

86. Lizzul, A.; Hellier, P.; Purton, S.; Baganz, F.; Ladommatos, N.; Campos, L. Combined remediation and lipid production using Chlorella sorokiniana grown on wastewater and exhaust gases. Bioresour. Technol. 2014, 151, 12-18. [CrossRef]

87. Fernández-Linares, L.C.; Barajas, C.G.; Páramo, E.D.; Corona, J.A.B. Assessment of Chlorella vulgaris and indigenous microalgae biomass with treated wastewater as growth culture medium. Bioresour. Technol. 2017, 244, 400-406. [CrossRef] 
88. Ge, S.; Qiu, S.; Tremblay, D.; Viner, K.; Champagne, P.; Jessop, P.G. Centrate wastewater treatment with Chlorella vulgaris: Simultaneous enhancement of nutrient removal, biomass and lipid production. Chem. Eng. J. 2018, 342, 310-320. [CrossRef]

89. Bibi, R.; Ditta, A.; Hussain, A.; Noureen, S.; Khalid, A.; Aziz, I. Production of algal biomass using different dilutions of textile effluent wastewater. Sci. Lett. 2016, 4, 71-77.

90. Lu, Q.; Zhou, W.; Min, M.; Ma, X.; Chandra, C.; Doan, Y.; Ma, Y.; Zheng, H.; Cheng, S.; Griffith, R.; et al. Growing Chlorella sp. on meat processing wastewater for nutrient removal and biomass production. Bioresour. Technol. 2015, 198, 189-197. [CrossRef] [PubMed]

91. Hou, Q.; Pei, H.; Hu, W.; Jiang, L.; Yu, Z. Mutual facilitations of food waste treatment, microbial fuel cell bioelectricity generation and Chlorella vulgaris lipid production. Bioresour. Technol. 2016, 203, 50-55. [CrossRef]

92. Tan, X.-B.; Zhao, X.-C.; Zhang, Y.-L.; Zhou, Y.-Y.; Yang, L.-B.; Zhang, W.-W. Enhanced lipid and biomass production using alcohol wastewater as carbon source for Chlorella pyrenoidosa cultivation in anaerobically digested starch wastewater in outdoors. Bioresour. Technol. 2018, 247, 784-793. [CrossRef]

93. Wang, S.-K.; Wang, X.; Miao, J.; Tian, Y.-T. Tofu whey wastewater is a promising basal medium for microalgae culture. Bioresour. Technol. 2018, 253, 79-84. [CrossRef]

94. Limayem, A.; Gonzalez, F.; Micciche, A.; Haller, E.; Nayak, B.; Mohapatra, S. Molecular identification and nanoremediation of microbial contaminants in algal systems using untreated wastewater. J. Environ. Sci. Health Part B 2016, 51, 868-872. [CrossRef] [PubMed]

95. Chang, H.-X.; Huang, Y.; Fu, Q.; Liao, Q.; Zhu, X. Kinetic characteristics and modeling of microalgae Chlorella vulgaris growth and $\mathrm{CO}_{2}$ biofixation considering the coupled effects of light intensity and dissolved inorganic carbon. Bioresour. Technol. 2016, 206, 231-238. [CrossRef] [PubMed]

96. Ogbonna, J.C.; Tanaka, H. Light requirement and photosynthetic cell cultivation-Development of processes for efficient light utilization in photobioreactors. Environ. Boil. Fishes 2000, 12, 207-218. [CrossRef]

97. Zhao, Y.; Wang, J.; Zhang, H.; Yan, C.; Zhang, Y. Effects of various LED light wavelengths and intensities on microalgae-based simultaneous biogas upgrading and digestate nutrient reduction process. Bioresour. Technol. 2013, 136, 461-468. [CrossRef]

98. Ma, R.; Thomas-Hall, S.R.; Chua, E.T.; Eltanahy, E.; Netzel, M.E.; Netzel, G.; Lu, Y.; Schenk, P.M. LED power efficiency of biomass, fatty acid, and carotenoid production in Nannochloropsis microalgae. Bioresour. Technol. 2018, 252, 118-126. [CrossRef]

99. Yan, C.; Muñoz, R.; Zhu, L.; Wang, Y. The effects of various LED (light emitting diode) lighting strategies on simultaneous biogas upgrading and biogas slurry nutrient reduction by using of microalgae Chlorella sp. Energy 2016, 106, 554-561. [CrossRef]

100. Kim, D.G.; Lee, C.; Park, S.-M.; Choi, Y.-E. Manipulation of light wavelength at appropriate growth stage to enhance biomass productivity and fatty acid methyl ester yield using Chlorella vulgaris. Bioresour. Technol. 2014, 159, 240-248. [CrossRef]

101. Zhao, Y.; Sun, S.; Hu, C.; Zhang, H.; Xu, J.; Ping, L. Performance of three microalgal strains in biogas slurry purification and biogas upgrade in response to various mixed light-emitting diode light wavelengths. Bioresour. Technol. 2015, 187, 338-345. [CrossRef] [PubMed]

102. Papone, T.; Kookkhunthod, S.; Paungbut, M.; Leesing, R. Producing of Microbial Oil by Mixed Culture of Microalgae and Oleaginous Yeast Using Sugarcane Molasses as Carbon Substrate. J. Clean Energy Technol. 2015, 4, 253-256. [CrossRef]

103. Sakarika, M.; Kornaros, M. Effect of $\mathrm{pH}$ on growth and lipid accumulation kinetics of the microalga Chlorella vulgaris grown heterotrophically under sulfur limitation. Bioresour. Technol. 2016, 219, 694-701. [CrossRef]

104. Liu, G.; Qiao, L.; Zhang, H.; Zhao, D.; Su, X. The effects of illumination factors on the growth and $\mathrm{HCO}_{3}{ }^{-}$fixation of microalgae in an experiment culture system. Energy 2014, 78, 40-47. [CrossRef]

105. Bell, T.A.S.; Prithiviraj, B.; Wahlen, B.; Fields, M.W.; Peyton, B.M. A Lipid-Accumulating Alga Maintains Growth in Outdoor, Alkaliphilic Raceway Pond with Mixed Microbial Communities. Front. Microbiol. 2016, 6, 1480. [CrossRef]

106. Kumar, A.; Ergas, S.; Yuan, X.; Sahu, A.; Zhang, Q.; Dewulf, J.; Malcata, F.X.; van Langenhove, H. Enhanced $\mathrm{CO}_{2}$ fixation and biofuel production via microalgae: Recent developments and future directions. Trends Biotechnol. 2010, 28, 371-380. [CrossRef]

107. LILLEY, R.M.; Ralph, P.J.; Larkum, A.W.D. The determination of activity of the enzyme Rubisco in cell extracts of the dinoflagellate alga Symbiodinium sp. by manganese chemiluminescence and its response to short-term thermal stress of the alga. Plant Cell Environ. 2010, 33, 995-1004. [CrossRef]

108. Béchet, Q.; Shilton, A.; Fringer, O.B.; Muñoz, R.; Guieysse, B. Mechanistic Modeling of Broth Temperature in Outdoor Photobioreactors. Environ. Sci. Technol. 2010, 44, 2197-2203. [CrossRef]

109. Béchet, Q.; Muñoz, R.; Shilton, A.; Guieysse, B. Outdoor cultivation of temperature-tolerantChlorella sorokinianain a column photobioreactor under low power-input. Biotechnol. Bioeng. 2013, 110, 118-126. [CrossRef] [PubMed]

110. Shuba, E.S.; Kifle, D. Microalgae to biofuels: 'Promising' alternative and renewable energy, review. Renew. Sust. Energ. Rev. 2018, 81, 743-755. [CrossRef]

111. Ramírez-López, C.; Perales-Vela, H.V.; Fernández-Linares, L. Biomass and lipid production from Chlorella vulgaris UTEX 26 cultivated in $2 \mathrm{~m} 3$ raceway ponds under semicontinuous mode during the spring season. Bioresour. Technol. 2019, 274, 252-260. [CrossRef]

112. Kusmayadi, A.; Philippidis, G.P.; Yen, H.-W. Application of computational fluid dynamics to raceways combining paddlewheel and $\mathrm{CO}_{2}$ spargers to enhance microalgae growth. J. Biosci. Bioeng. 2020, 129, 93-98. [CrossRef] 
113. López-Rosales, L.; Sánchez-Mirón, A.; Contreras-Gómez, A.; García-Camacho, F.; Battaglia, F.; Zhao, L.; Molina-Grima, E. Characterization of bubble column photobioreactors for shear-sensitive microalgae culture. Bioresour. Technol. 2019, $275,1-9$. [CrossRef]

114. Lam, M.K.; Khoo, C.G.; Lee, K.T. Chapter 19-Scale-up and commercialization of algal cultivation and biofuels production. In Biofuels from Algae, 2nd ed.; Pandey, A., Chang, J.S., Soccol, C.R., Lee, D.J., Chisti, Y., Eds.; Elsevier: Amsterdam, The Netherlands, 2019; pp. 475-506.

115. Barceló-Villalobos, M.; Olmo, P.F.-D.; Guzman, J.L.; Sevilla, J.M.F.; Fernández, F.A. Evaluation of photosynthetic light integration by microalgae in a pilot-scale raceway reactor. Bioresour. Technol. 2019, 280, 404-411. [CrossRef]

116. Rastogi, R.P.; Pandey, A.; Larroche, C.; Madamwar, D. Algal Green Energy-R\&D and technological perspectives for biodiesel production. Renew. Sustain. Energy Rev. 2018, 82, 2946-2969. [CrossRef]

117. Xu, J.; Cheng, J.; Xin, K.; Xu, J.; Yang, W. Strengthening flash light effect with a pond-tubular hybrid photobioreactor to improve microalgal biomass yield. Bioresour. Technol. 2020, 318, 124079. [CrossRef]

118. Senatore, V.; Buonerba, A.; Zarra, T.; Oliva, G.; Belgiorno, V.; Boguniewicz-Zablocka, J.; Naddeo, V. Innovative membrane photobioreactor for sustainable $\mathrm{CO}_{2}$ capture and utilization. Chemosphere 2021, 273, 129682. [CrossRef] [PubMed]

119. Zhang, C.-D.; Li, W.; Shi, Y.-H.; Li, Y.-G.; Huang, J.-K.; Li, H.-X. A new technology of $\mathrm{CO}_{2}$ supplementary for microalgae cultivation on large scale-A spraying absorption tower coupled with an outdoor open runway pond. Bioresour. Technol. 2016, 209, 351-359. [CrossRef]

120. Wong, Y.K.; Ho, K.C.; Tsang, Y.F.; Wang, L.; Yung, K.K.L. Cultivation of Chlorella vulgaris in Column Photobioreactor for Biomass Production and Lipid Accumulation. Water Environ. Res. 2016, 88, 40-46. [CrossRef] [PubMed]

121. Adamczyk, M.; Lasek, J.; Skawińska, A. $\mathrm{CO}_{2}$ Biofixation and Growth Kinetics of Chlorella vulgaris and Nannochloropsis gaditana. Appl. Biochem. Biotechnol. 2016, 179, 1248-1261. [CrossRef]

122. Khoo, C.G.; Lam, M.K.; Lee, K.T. Pilot-scale semi-continuous cultivation of microalgae Chlorella vulgaris in bubble column photobioreactor (BC-PBR): Hydrodynamics and gas-liquid mass transfer study. Algal Res. 2016, 15, 65-76. [CrossRef]

123. Gong, M.; Bassi, A. Investigation of Chlorella vulgaris UTEX 265 Cultivation under Light and Low Temperature Stressed Conditions for Lutein Production in Flasks and the Coiled Tree Photo-Bioreactor (CTPBR). Appl. Biochem. Biotechnol. 2017, 183, 652-671. [CrossRef]

124. Qiu, R.; Gao, S.; Lopez, P.A.; Ogden, K.L. Effects of $\mathrm{pH}$ on cell growth, lipid production and $\mathrm{CO}_{2}$ addition of microalgae Chlorella sorokiniana. Algal Res. 2017, 28, 192-199. [CrossRef]

125. Ren, H.; Tuo, J.; Addy, M.M.; Zhang, R.; Lu, Q.; Anderson, E.; Chen, P.; Ruan, R. Cultivation of Chlorella vulgaris in a pilot-scale photobioreactor using real centrate wastewater with waste glycerol for improving microalgae biomass production and wastewater nutrients removal. Bioresour. Technol. 2017, 245, 1130-1138. [CrossRef]

126. Nayak, M.; Suh, W.I.; Lee, B.; Chang, Y.K. Enhanced carbon utilization efficiency and FAME production of Chlorella sp. HS2 through combined supplementation of bicarbonate and carbon dioxide. Energy Convers. Manag. 2018, 156, 45-52. [CrossRef]

127. Suparmaniam, U.; Lam, M.K.; Uemura, Y.; Lim, J.W.; Lee, K.T.; Shuit, S.H. Insights into the microalgae cultivation technology and harvesting process for biofuel production: A review. Renew. Sustain. Energy Rev. 2019, 115, 109361. [CrossRef]

128. Su, Y.; Song, K.; Zhang, P.; Su, Y.; Cheng, J.; Chen, X. Progress of microalgae biofuel's commercialization. Renew. Sustain. Energy Rev. 2017, 74, 402-411. [CrossRef]

129. Kesieme, U.; Pazouki, K.; Murphy, A.; Chrysanthou, A. Biofuel as an alternative shipping fuel: Technological, environmental and economic assessment. Sustain. Energy Fuels 2019, 3, 899-909. [CrossRef]

130. Vasistha, S.; Khanra, A.; Clifford, M.; Rai, M. Current advances in microalgae harvesting and lipid extraction processes for improved biodiesel production: A review. Renew. Sustain. Energy Rev. 2021, 137, 110498. [CrossRef]

131. Arun, J.; Gopinath, K.P.; Sivaramakrishnan, R.; SundarRajan, P.; Malolan, R.; Pugazhendhi, A. Technical insights into the production of green fuel from $\mathrm{CO}_{2}$ sequestered algal biomass: A conceptual review on green energy. Sci. Total Environ. 2021, 755, 142636. [CrossRef]

132. Yusoff, M.N.A.M.; Zulkifli, N.W.M.; Masum, B.; Masjuki, H.H. Feasibility of bioethanol and biobutanol as transportation fuel in spark-ignition engine: A review. RSC Adv. 2015, 5, 100184-100211. [CrossRef]

133. Wang, Y.; Ho, S.-H.; Cheng, C.-L.; Nagarajan, D.; Guo, W.-Q.; Lin, C.; Li, S.; Ren, N.; Chang, J.-S. Nutrients and COD removal of swine wastewater with an isolated microalgal strain Neochloris aquatica CL-M1 accumulating high carbohydrate content used for biobutanol production. Bioresour. Technol. 2017, 242, 7-14. [CrossRef]

134. Yeong, T.K.; Jiao, K.; Zeng, X.; Lin, L.; Pan, S.; Danquah, M.K. Microalgae for biobutanol production-Technology evaluation and value proposition. Algal Res. 2018, 31,367-376. [CrossRef]

135. Ho, S.-H.; Huang, S.-W.; Chen, C.-Y.; Hasunuma, T.; Kondo, A.; Chang, J.-S. Characterization and optimization of carbohydrate production from an indigenous microalga Chlorella vulgaris FSP-E. Bioresour. Technol. 2013, 135, 157-165. [CrossRef]

136. Wang, Y.; Guo, W.; Cheng, C.-L.; Ho, S.-H.; Chang, J.-S.; Ren, N. Enhancing bio-butanol production from biomass of Chlorella vulgaris JSC-6 with sequential alkali pretreatment and acid hydrolysis. Bioresour. Technol. 2016, 200, 557-564. [CrossRef]

137. Onay, M. Investigation of Biobutanol Efficiency of Chlorella sp. Cultivated in Municipal Wastewater. J. Geosci. Environ. Prot. 2018, 6, 40-50. [CrossRef]

138. Angelidaki, I.; Treu, L.; Tsapekos, P.; Luo, G.; Campanaro, S.; Wenzel, H.; Kougias, P.G. Biogas upgrading and utilization: Current status and perspectives. Biotechnol. Adv. 2018, 36, 452-466. [CrossRef] 
139. Zabed, H.M.; Akter, S.; Yun, J.; Zhang, G.; Zhang, Y.; Qi, X. Biogas from microalgae: Technologies, challenges and opportunities. Renew. Sustain. Energy Rev. 2020, 117, 109503. [CrossRef]

140. Kendir, E.; Uğurlu, A. A comprehensive review on pretreatment of microalgae for biogas production. Int. J. Energy Res. 2018, 42, 3711-3731. [CrossRef]

141. Mahdy, A.; Mendez, L.; Ballesteros, M.; González-Fernández, C. Algaculture integration in conventional wastewater treatment plants: Anaerobic digestion comparison of primary and secondary sludge with microalgae biomass. Bioresour. Technol. 2015, 184, 236-244. [CrossRef]

142. Kavitha, S.; Subbulakshmi, P.; Banu, J.R.; Gobi, M.; Yeom, I.T. Enhancement of biogas production from microalgal biomass through celluloltyic bacterial pretreatment. Bioresour. Technol. 2017, 233, 34-43. [CrossRef]

143. Lavrič, L.; Cerar, A.; Fanedl, L.; Lazar, B.; Žitnik, M.; Logar, R.M. Thermal pretreatment and bioaugmentation improve methane yield of microalgal mix produced in thermophilic anaerobic digestate. Anaerobe 2017, 46, 162-169. [CrossRef]

144. Li, R.; Duan, N.; Zhang, Y.; Liu, Z.; Li, B.; Zhang, D.; Lu, H.; Dong, T. Co-digestion of chicken manure and microalgae Chlorella 1067 grown in the recycled digestate: Nutrients reuse and biogas enhancement. Waste Manag. 2017, 70, 247-254. [CrossRef] [PubMed]

145. Guo, P.; Zhang, Y.; Zhao, Y. Biocapture of $\mathrm{CO}_{2}$ by Different Microalgal-Based Technologies for Biogas Upgrading and Simultaneous Biogas Slurry Purification under Various Light Intensities and Photoperiods. Int. J. Environ. Res. Public Health 2018, 15, 528. [CrossRef]

146. Kao, C.-Y.; Chiu, S.-Y.; Huang, T.-T.; Dai, L.; Wang, G.-H.; Tseng, C.-P.; Chen, C.-H.; Lin, C.-S. A mutant strain of microalga Chlorella sp. for the carbon dioxide capture from biogas. Biomass Bioenergy 2012, 36, 132-140. [CrossRef]

147. Souvannasouk, V.; Shen, M.-Y.; Trejo, M.; Bhuyar, P. Biogas production from Napier grass and cattle slurry using a green energy technology. Int. J. Innov. Res. Sci. Stud. 2021, 4, 174-180. [CrossRef]

148. Jadhav, P.; Nasrullah, M.; Zularisam, A.W.; Bhuyar, P.; Krishnan, S.; Mishra, P. Direct interspecies electron transfer performance through nanoparticles (NPs) for biogas production in the anaerobic digestion process. Int. J. Environ. Sci. Technol. 2021, 1-13. [CrossRef]

149. Bwapwa, J.K.; Anandraj, A.; Trois, C. Microalgae processing for jet fuel production. Biofuels Bioprod. Biorefining 2018, 12, 522-535. [CrossRef]

150. Savage, N. Fuel options: The ideal biofuel. Nat. Cell Biol. 2011, 474, S9-S11. [CrossRef]

151. Chiu, S.-Y.; Kao, C.-Y.; Tsai, M.-T.; Ong, S.-C.; Chen, C.-H.; Lin, C.-S. Lipid accumulation and $\mathrm{CO}_{2}$ utilization of Nannochloropsis oculata in response to $\mathrm{CO}_{2}$ aeration. Bioresour. Technol. 2009, 100, 833-838. [CrossRef] [PubMed]

152. Bwapwa, J.K.; Anandraj, A.; Trois, C. Possibilities for conversion of microalgae oil into aviation fuel: A review. Renew. Sustain. Energy Rev. 2017, 80, 1345-1354. [CrossRef]

153. Mona, S.; Malyan, S.K.; Saini, N.; Deepak, B.; Pugazhendhi, A.; Kumar, S.S. Towards sustainable agriculture with carbon sequestration, and greenhouse gas mitigation using algal biochar. Chemosphere 2021, 275, 129856. [CrossRef]

154. Binda, G.; Spanu, D.; Bettinetti, R.; Magagnin, L.; Pozzi, A.; Dossi, C. Comprehensive comparison of microalgae-derived biochar from different feedstocks: A prospective study for future environmental applications. Algal Res. 2020, 52, 102103. [CrossRef]

155. Duan, S.; Chen, Y.; Yan, Y.; Feng, L.; Chen, Y.; Zhou, Q. New method for algae comprehensive utilization: Algae-derived biochar enhances algae anaerobic fermentation for short-chain fatty acids production. Bioresour. Technol. 2019, 289, 121637. [CrossRef]

156. Amin, M.; Chetpattananondh, P. Biochar from extracted marine Chlorella sp. residue for high efficiency adsorption with ultrasonication to remove $\mathrm{Cr}(\mathrm{VI}), \mathrm{Zn}(\mathrm{II})$ and Ni(II). Bioresour. Technol. 2019, 289, 121578. [CrossRef]

157. Ni Law, X.; Cheah, W.Y.; Chew, K.W.; Ibrahim, M.F.; Park, Y.-K.; Ho, S.-H.; Show, P.L. Microalgal-based biochar in wastewater remediation: Its synthesis, characterization and applications. Environ. Res. 2021, 204, 111966. [CrossRef]

158. Manyuchi, M.; Mbohwa, C.; Muzenda, E. Potential to use municipal waste bio char in wastewater treatment for nutrients recovery. Phys. Chem. Earth Parts A/B/C 2018, 107, 92-95. [CrossRef]

159. Mutum, L.; Janda, T.; Ördög, V.; Molnár, Z. Biologia Futura: Potential of different forms of microalgae for soil improvement. Biol. Futur. 2021, 1-8. [CrossRef] [PubMed]

160. Xiang, W.; Zhang, X.; Chen, J.; Zou, W.; He, F.; Hu, X.; Tsang, D.; Ok, Y.S.; Gao, B. Biochar technology in wastewater treatment: A critical review. Chemosphere 2020, 252, 126539. [CrossRef]

161. Chen, P.-T.; Hong, Z.-S.; Cheng, C.-L.; Ng, I.-S.; Lo, Y.-C.; Nagarajan, D.; Chang, J.-S. Exploring fermentation strategies for enhanced lactic acid production with polyvinyl alcohol-immobilized Lactobacillus plantarum 23 using microalgae as feedstock. Bioresour. Technol. 2020, 308, 123266. [CrossRef] [PubMed]

162. Xia, M.; Shen, Z.; Gu, M.; Chen, W.; Dong, W.; Zhang, Y. Efficient catalytic conversion of microalgae residue solid waste into lactic acid over a Fe-Sn-Beta catalyst. Sci. Total Environ. 2021, 771, 144891. [CrossRef]

163. Sorokina, K.N.; Samoylova, Y.V.; Gromov, N.V.; Ogorodnikova, O.L.; Parmon, V.N. Production of biodiesel and succinic acid from the biomass of the microalga Micractinium sp. IC-44. Bioresour. Technol. 2020, 317, 124026. [CrossRef] [PubMed]

164. Liu, K.; Huang, X.; Pidko, E.A.; Hensen, E.J.M. Hydrogenation of Lactic Acid to 1,2-Propanediol over Ru-Based Catalysts. ChemCatChem 2017, 10, 810-817. [CrossRef] [PubMed]

165. Knoshaug, E.P.; Mohagheghi, A.; Nagle, N.J.; Stickel, J.J.; Dong, T.; Karp, E.M.; Kruger, J.S.; Brandner, D.G.; Manker, L.P.; Rorrer, N.A.; et al. Demonstration of parallel algal processing: Production of renewable diesel blendstock and a high-value chemical intermediate. Green Chem. 2018, 20, 457-468. [CrossRef] 
166. Amorim, M.L.; Soares, J.; Coimbra, J.S.D.R.; Leite, M.D.O.; Albino, L.F.T.; Martins, M.A. Microalgae proteins: Production, separation, isolation, quantification, and application in food and feed. Crit. Rev. Food Sci. Nutr. 2021, 61, 1976-2002. [CrossRef]

167. Silva, S.C.; Ferreira, I.C.F.R.; Dias, M.M.; Barreiro, M.F. Microalgae-Derived Pigments: A 10-Year Bibliometric Review and Industry and Market Trend Analysis. Molecules 2020, 25, 3406. [CrossRef]

168. Lafarga, T. Effect of microalgal biomass incorporation into foods: Nutritional and sensorial attributes of the end products. Algal Res. 2019, 41, 101566. [CrossRef]

169. Caporgno, M.P.; Mathys, A. Trends in Microalgae Incorporation into Innovative Food Products with Potential Health Benefits. Front. Nutr. 2018, 5, 58. [CrossRef]

170. Zhang, J.; He, Y.; Luo, M.; Chen, F. Utilization of enzymatic cell disruption hydrolysate of Chlorella pyrenoidosa as potential carbon source in algae mixotrophic cultivation. Algal Res. 2020, 45, 101730. [CrossRef]

171. Zaki, M.I.; Saad, H. Comparative study on growth and survival of larval and juvenile Dicentrarchus labrax rearing on rotifer and Artemia enriched with four different microalgae species. Afr. J. Biotechnol. 2010, 9, 3676-3688.

172. Ortuño, J.; Esteban, M.Á.; Meseguer, J. The effect of dietary intake of vitamins C and E on the stress response of gilthead seabream (Sparus aurata L.). Fish Shellfish. Immunol. 2003, 14, 145-156. [CrossRef]

173. Hikima, J.-I.; Ando, M.; Hamaguchi, H.-O.; Sakai, M.; Maita, M.; Yazawa, K.; Takeyama, H.; Aoki, T. On-site Direct Detection of Astaxanthin from Salmon Fillet Using Raman Spectroscopy. Mar. Biotechnol. 2017, 19, 157-163. [CrossRef]

174. Bleakley, S.; Hayes, M. Algal Proteins: Extraction, Application, and Challenges Concerning Production. Foods 2017, 6, 33. [CrossRef]

175. Liao, S.F.; Wang, T.; Regmi, N. Lysine nutrition in swine and the related monogastric animals: Muscle protein biosynthesis and beyond. SpringerPlus 2015, 4, 147. [CrossRef] [PubMed]

176. Noreen, A.; Mahmood, S.; Aziz, I.; Takriff, M.S.; Gulzar, S.; Ditta, A.; Khalid, A.; Mahmood, T. Microalgae as potential protein sources: Evidence from protein extraction and amino acid profiling of Chlorella vulgaris and Scenedesmus sp. Pak. J. Agric. Sci. 2021, 58, 821-829.

177. El-Abd, N.M.; Hamouda, R.A.E.F. Improved productivity and health of broiler chicken by micro green alga Chlorella vulgaris. Asian J. Poult. Sci. 2017, 11, 57-63.

178. Skov, J.; Kania, P.W.; Holten-Andersen, L.; Fouz, B.; Buchmann, K. Immunomodulatory effects of dietary $\beta$-1,3-glucan from Euglena gracilis in rainbow trout (Oncorhynchus mykiss) immersion vaccinated against Yersinia ruckeri. Fish Shellfish. Immunol. 2012, 33, 111-120. [CrossRef] [PubMed]

179. Świątkiewicz, S.; Arczewska-Włosek, A.; Józefiak, D. Application of microalgae biomass in poultry nutrition. World's Poult. Sci. J. 2015, 71, 663-672. [CrossRef]

180. Andriola, Y.T.; Moreira, F.; Anastácio, E.; Camelo, F.A., Jr.; Silva, A.C.; Varela, A.S.; Gheller, S.M.M.; Goularte, K.L.; Corcini, C.D.; Lucia, T., Jr. Boar sperm quality after supplementation of diets with omega-3 polyunsaturated fatty acids extracted from microalgae. Andrologia 2018, 50, e12825. [CrossRef]

181. Moran, C.A.; Morlacchini, M.; Keegan, J.D.; Delles, R.; Fusconi, G. Effects of a DHA-rich unextracted microalgae as a dietary supplement on performance, carcass traits and meat fatty acid profile in growing-finishing pigs. J. Anim. Physiol. Anim. Nutr. 2018, 102, 1026-1038. [CrossRef]

182. Zaheer, K. Hen egg carotenoids (lutein and zeaxanthin) and nutritional impacts on human health: A review. CyTA J. Food 2017, 15, 474-487. [CrossRef]

183. Liu, B.; Jiang, J.; Yu, D.; Lin, G.; Xiong, Y. Effects of Supplementation of Microalgae (Aurantiochytrium sp.) to Laying Hen Diets on Fatty Acid Content, Health Lipid Indices, Oxidative Stability, and Quality Attributes of Meat. Foods 2020, 9, 1271. [CrossRef] [PubMed]

184. Mehta, P.; Singh, D.; Saxena, R.; Rani, R.; Gupta, R.P.; Puri, S.K.; Mathur, A.S. High-Value Coproducts from Algae-an Innovational Way to Deal with Advance Algal Industry. In Waste to Wealth; Singhania, R.R., Agarwal, R.A., Kumar, R.P., Sukumaran, R.K., Eds.; Springer: Singapore, 2017; pp. 343-363.

185. Rincón, B.; Fernández-Rodríguez, M.J.; de la Lama-Calvente, D.; Borja, R. Chapter 4 The influence of microalgae addition as co-substrate in anaerobic digestion processes. In Microalgal Biotechnology, 1st ed.; Jacob-Lopes, E., Zepka, L.Q., Queiroz, M.I., Eds.; IntechOpen: London, UK, 2018; pp. 59-90.

186. Xie, Y.; Li, J.; Ho, S.-H.; Ma, R.; Shi, X.; Liu, L.; Chen, J. Pilot-scale cultivation of Chlorella sorokiniana FZU60 with a mixotrophy/photoautotrophy two-stage strategy for efficient lutein production. Bioresour. Technol. 2020, 314, 123767. [CrossRef]

187. Mulders, K.J.M.; Weesepoel, Y.; Bodenes, P.; Lamers, P.; Vincken, J.-P.; Martens, D.E.; Gruppen, H.; Wijffels, R.H. Nitrogendepleted Chlorella zofingiensis produces astaxanthin, ketolutein and their fatty acid esters: A carotenoid metabolism study. Environ. Boil. Fishes 2015, 27, 125-140. [CrossRef]

188. Novoveská, L.; Ross, M.E.; Stanley, M.S.; Pradelles, R.; Wasiolek, V.; Sassi, J.-F. Microalgal Carotenoids: A Review of Production, Current Markets, Regulations, and Future Direction. Mar. Drugs 2019, 17, 640. [CrossRef]

189. Singh, D.; Barrow, C.J.; Mathur, A.S.; Tuli, D.K.; Puri, M. Optimization of zeaxanthin and $\beta$-carotene extraction from Chlorella saccharophila isolated from New Zealand marine waters. Biocatal. Agric. Biotechnol. 2015, 4, 166-173. [CrossRef]

190. Liu, J.; Mao, X.; Zhou, W.; Guarnieri, M.T. Simultaneous production of triacylglycerol and high-value carotenoids by the astaxanthin-producing oleaginous green microalga Chlorella zofingiensis. Bioresour. Technol. 2016, 214, 319-327. [CrossRef] [PubMed] 
191. Ribeiro, J.E.S.; Martini, M.; Altomonte, I.; Salari, F.; Nardoni, S.; Sorce, C.; da Silva, F.L.H.; Andreucci, A. Production of Chlorella protothecoides biomass, chlorophyll and carotenoids using the dairy industry by-product scotta as a substrate. Biocatal. Agric. Biotechnol. 2017, 11, 207-213. [CrossRef]

192. Zhang, Z.; Huang, J.J.; Sun, D.; Lee, Y.; Chen, F. Two-step cultivation for production of astaxanthin in Chlorella zofingiensis using a patented energy-free rotating floating photobioreactor (RFP). Bioresour. Technol. 2017, 224, 515-522. [CrossRef] [PubMed]

193. Huang, W.; Lin, Y.; He, M.; Gong, Y.; Huang, J. Induced High-Yield Production of Zeaxanthin, Lutein, and $\beta$-Carotene by a Mutant of Chlorella zofingiensis. J. Agric. Food Chem. 2018, 66, 891-897. [CrossRef]

194. Mao, X.; Wu, T.; Sun, D.; Zhang, Z.; Chen, F. Differential responses of the green microalga Chlorella zofingiensis to the starvation of various nutrients for oil and astaxanthin production. Bioresour. Technol. 2018, 249, 791-798. [CrossRef]

195. Chen, J.-H.; Kato, Y.; Matsuda, M.; Chen, C.-Y.; Nagarajan, D.; Hasunuma, T.; Kondo, A.; Chang, J.-S. Lutein production with Chlorella sorokiniana MB-1-M12 using novel two-stage cultivation strategies-metabolic analysis and process improvement. Bioresour. Technol. 2021, 334, 125200. [CrossRef]

196. Richardson, J.W.; Johnson, M.D.; Zhang, X.; Zemke, P.; Chen, W.; Hu, Q. A financial assessment of two alternative cultivation systems and their contributions to algae biofuel economic viability. Algal Res. 2014, 4, 96-104. [CrossRef]

197. Bello, M.; Ranganathan, P.; Brennan, F. Life Cycle Optimization for Sustainable Algal Biofuel Production Using Integrated Nutrient Recycling Technology. ACS Sustain. Chem. Eng. 2017, 5, 9869-9880. [CrossRef]

198. Wu, W.; Lin, K.-H.; Chang, J.-S. Economic and life-cycle greenhouse gas optimization of microalgae-to-biofuels chains. Bioresour. Technol. 2018, 267, 550-559. [CrossRef]

199. Sun, J.; Xiong, X.; Wang, M.; Du, H.; Li, J.; Zhou, D.; Zuo, J. Microalgae biodiesel production in China: A preliminary economic analysis. Renew. Sustain. Energy Rev. 2019, 104, 296-306. [CrossRef]

200. Giwa, A.; Adeyemi, I.; Dindi, A.; García-Bañoz Lopez, C.; Lopresto, C.G.; Curcio, S.; Chakraborty, S. Techno-economic assessment of the sustainability of an integrated biorefinery from microalgae and Jatropha: A review and case study. Renew. Sustain. Energy Rev. 2018, 88, 239-257. [CrossRef]

201. Hanifzadeh, M.; Sarrafzadeh, M.-H.; Nabati, Z.; Tavakoli, O.; Feyzizarnagh, H. Technical, economic and energy assessment of an alternative strategy for mass production of biomass and lipid from microalgae. J. Environ. Chem. Eng. 2018, 6, 866-873. [CrossRef]

202. Ranganathan, P.; Savithri, S. Techno-economic analysis of microalgae-based liquid fuels production from wastewater via hydrothermal liquefaction and hydroprocessing. Bioresour. Technol. 2019, 284, 256-265. [CrossRef] [PubMed]

203. Silva, M.; Gonçalves, A.; Vilar, V.; Pires, J. Experimental and Techno-Economic Study on the Use of Microalgae for Paper Industry Effluents Remediation. Sustainability 2021, 13, 1314. [CrossRef]

204. Quinn, J.C.; Davis, R. The potentials and challenges of algae based biofuels: A review of the techno-economic, life cycle, and resource assessment modeling. Bioresour. Technol. 2015, 184, 444-452. [CrossRef] [PubMed]

205. Menten, F.; Chèze, B.; Patouillard, L.; Bouvart, F. A review of LCA greenhouse gas emissions results for advanced biofuels: The use of meta-regression analysis. Renew. Sustain. Energy Rev. 2013, 26, 108-134. [CrossRef]

206. Tu, Q.; Eckelman, M.; Zimmerman, J. Meta-analysis and Harmonization of Life Cycle Assessment Studies for Algae Biofuels. Environ. Sci. Technol. 2017, 51, 9419-9432. [CrossRef] [PubMed]

207. Wu, W.; Lei, Y.-C.; Chang, J.-S. Life cycle assessment of upgraded microalgae-to-biofuel chains. Bioresour. Technol. 2019, 288, 121492. [CrossRef]

208. Saranya, G.; Ramachandra, T. Life cycle assessment of biodiesel from estuarine microalgae. Energy Convers. Manag. X 2020, 8 , 100065. [CrossRef]

209. Khan, M.I.; Shin, J.H.; Kim, J.D. The promising future of microalgae: Current status, challenges, and optimization of a sustainable and renewable industry for biofuels, feed, and other products. Microb. Cell Fact. 2018, 17, 36. [CrossRef] [PubMed]

210. Lv, J.; Feng, J.; Liu, Q.; Xie, S. Microalgal Cultivation in Secondary Effluent: Recent Developments and Future Work. Int. J. Mol. Sci. 2017, 18, 79. [CrossRef]

211. Yadav, G.; Dash, S.K.; Sen, R. A biorefinery for valorization of industrial waste-water and flue gas by microalgae for waste mitigation, carbon-dioxide sequestration and algal biomass production. Sci. Total Environ. 2019, 688, 129-135. [CrossRef]

212. Zhao, Y.; Wang, H.-P.; Han, B.; Yu, X. Coupling of abiotic stresses and phytohormones for the production of lipids and high-value by-products by microalgae: A review. Bioresour. Technol. 2019, 274, 549-556. [CrossRef]

213. Fasaei, F.; Bitter, J.; Slegers, P.; van Boxtel, A. Techno-economic evaluation of microalgae harvesting and dewatering systems. Algal Res. 2018, 31, 347-362. [CrossRef]

214. Muhammad, G.; Alam, M.A.; Mofijur, M.; Jahirul, M.I.; Lv, Y.; Xiong, W.; Ong, H.C.; Xu, J. Modern developmental aspects in the field of economical harvesting and biodiesel production from microalgae biomass. Renew. Sustain. Energy Rev. 2020, 135, 110209. [CrossRef]

215. Jerney, J.; Spilling, K. Large scale cultivation of microalgae: Open and closed systems. Methods Mol. Biol. 2020, $1980,1-8$.

216. Aratboni, H.A.; Rafiei, N.; Garcia-Granados, R.; Alemzadeh, A.; Morones-Ramírez, J.R. Biomass and lipid induction strategies in microalgae for biofuel production and other applications. Microb. Cell Factories 2019, 18, 178. [CrossRef] [PubMed]

217. Li, X.; Wang, X.; Duan, C.; Yi, S.; Gao, Z.; Xiao, C.; Agathos, S.N.; Wang, G.; Li, J. Biotechnological production of astaxanthin from the microalga Haematococcus pluvialis. Biotechnol. Adv. 2020, 43, 107602. [CrossRef] [PubMed] 